\title{
Late Holocene covariability of the southern westerlies and sea surface temperature in northern Chilean Patagonia
}

\author{
Sébastien Bertrand ${ }^{\mathrm{a}, \mathrm{b},{ }^{*}, \text { Konrad Hughen }}{ }^{\mathrm{a}}$, Julio Sepúlveda ${ }^{\mathrm{c}}$, Silvio Pantoja ${ }^{\mathrm{d}}$ \\ ${ }^{a}$ Marine Chemistry and Geochemistry, Woods Hole Oceanographic Institution, 360 Woods Hole Road, MA 02543, Woods Hole, USA \\ ${ }^{\mathrm{b}}$ Renard Centre of Marine Geology, Ghent University, Krijgslaan 281 S8, 9000, Gent, Belgium \\ ${ }^{\mathrm{c}}$ Department of Geological Sciences and Institute of Arctic and Alpine Research (INSTAAR), University of Colorado Boulder, 450 UCB, Boulder, CO 80309, USA \\ ${ }^{\mathrm{d}}$ Department of Oceanography and COPAS-Sur Austral Program, University of Concepción, Barrio Universitario s/n, Concepción, Chile
}

\section{A R T I C L E I N F O}

\section{Article history:}

Received 19 February 2014

Received in revised form

15 September 2014

Accepted 26 September 2014

Available online 28 October 2014

\section{Keywords:}

Southern westerlies

Inorganic geochemistry

Paleohydrology

Paleohydroclimatology

Fjord sediments

Southern South America

Chilean Patagonia

\begin{abstract}
A B S T R A C T
The climate of Chilean Patagonia is strongly influenced by the southern westerlies, which control the amount and latitudinal distribution of precipitation in the southern Andes. In austral summer, the Southern Westerly Wind Belt (SWWB) is restricted to the high latitudes. It expands northward in winter, which results in a strong precipitation seasonality between $\sim 35$ and $45^{\circ} \mathrm{S}$. Here, we present a new precipitation seasonality proxy record from Quitralco fjord $\left(46^{\circ} S\right)$, where relatively small latitudinal shifts of the SWWB result in large changes in precipitation seasonality. Our $1400 \mathrm{yr}$ record is based on sedimentological and geochemical data obtained on a sediment core collected in front of a small river that drains the Patagonian Andes, which makes this site particularly sensitive to changes in river discharge. Our results indicate Fe/Al and Ti/Al values that are low between 600 and $1200 \mathrm{CE}$, increasing at 1200-1500 CE, and high between 1500 and $1950 \mathrm{CE}$. Increasing $\mathrm{Fe} / \mathrm{Al}$ and Ti/Al values reflect a decrease in mean sediment grain-size from 30 to $20 \mu \mathrm{m}$, which is interpreted as a decrease in seasonal floods resulting from an equatorward shift of the SWWB. Our results suggest that, compared to present-day conditions, the SWWB was located in a more poleward position before $1200 \mathrm{CE}$. It gradually shifted towards the equator in 1200-1500 CE, where it remained in a sustained position until $1950 \mathrm{CE}$. This pattern is consistent with most precipitation records from central and southern Chile. The comparison of our record with published regional sea surface temperature (SST) reconstructions for the late Holocene shows that equatorward shifts of the SWWB are systematically coeval with decreasing SSTs and vice versa, which resembles fluctuations over glacial-interglacial timescales. We argue that the synchronicity between SST and SWWB changes during the last 1400 years represents the response of the SWWB to temperature changes in the Southern Hemisphere.
\end{abstract}

() 2014 Elsevier Ltd. All rights reserved.

\section{Introduction}

The southern westerlies are the prevailing winds at the mid latitudes of the Southern Hemisphere, blowing between the subtropical anticyclone and the cyclonic subpolar air masses. The Southern Westerly Wind Belt (SWWB) extends roughly between 30 and $60^{\circ} \mathrm{S}$, and it exhibits latitudinal variations at seasonal to glacial-interglacial timescales. Due to the absence of continental barriers in the Southern Ocean, the SWWB directly controls the

\footnotetext{
* Corresponding author. Renard Centre of Marine Geology, Ghent University, Krijgslaan 281 S8, 9000, Gent, Belgium. Tel.: +3292644637; fax: +3292644967. E-mail addresses: sbertrand@whoi.edu, sebastien.bertrand@ugent.be (S. Bertrand).
}

strength of the Antarctic Circumpolar Current (ACC), which in turn modulates the release of $\mathrm{CO}_{2}$ from the deep ocean up to the atmosphere, particularly on glacial-interglacial timescales (Anderson et al., 2009). In addition to modulating the strength of the ACC, the SWWB also controls the amount of precipitation on the windward side of the mountain ranges located along its path such as the southern Andes and the southern Alps of New Zealand. In western Patagonia, high westerly-driven precipitation supports extensive rainforests and large rivers, and it sustains the temperate glaciers that compose the Patagonian icefields and Darwin Cordillera (Masiokas et al., 2008; Garreaud et al., 2013). As a result, precipitation variability in the southwestern Andes is one of the most important factors that control Patagonian glacier mass balance at centennial to millennial timescales (Bertrand et al., 2012a; Boex 
et al., 2013). In the last decades, the SWWB has migrated poleward, causing a decrease in annual precipitation in southern Chile, which accelerated glacier retreat in Patagonia (e.g., Warren, 1993; Masiokas et al., 2008), increased desertification in northern Chile (e.g., Salinas and Mendieta, 2013), and reduced the amount of freshwater available for irrigation and consumption (Minetti et al., 2003; Meza, 2013). Given the impact that the SWWB has on global atmospheric $\mathrm{CO}_{2}$ concentrations, and on the environment and socio-economic activities in South America, it is crucial to understand how its variations relate to changes in the global atmospheric and oceanic systems.

Southern Chile is ideally located to reconstruct past changes in the SWWB because it is the only continuous land mass that intersects the core and the entire northern half of the SWWB. In addition, due the orographic effect of the Andes, the SWWB almost entirely controls precipitation on the western side of the Andes. Paleohydrological records from Chilean Patagonia therefore constitute one of the best ways to reconstruct past changes in the SWWB.

At glacial-interglacial timescales, the SWBB displays latitudinal variations of up to 10 degrees of latitude, which are closely related to global temperature changes (Toggweiler et al., 2006). The SWWB is generally located in an equatorward position under cold glacial conditions, and it shifts poleward during warm interglacials (Toggweiler et al., 2006; Kohfeld et al., 2013; Lamy et al., 2014). This behavior differs from present-day seasonal variations, during which the SWWB does not significantly shift latitudinally but rather shows a contraction in austral summer and an expansion in austral winter (Garreaud et al., 2009; Lamy et al., 2010). On intermediate timescales, high frequency changes in the SWWB are increasingly interpreted as reflecting variations in the Southern Annual Mode (SAM; e.g., Villalba et al., 2012; Moreno et al., 2014).

Although SWWB variability at seasonal (Garreaud et al., 2009, 2013) and glacial-interglacial (Kohfeld et al., 2013) timescales is relatively well understood, a lot of uncertainties remain regarding SWWB variations on centennial timescales during the Holocene (e.g., Kilian and Lamy, 2012). For more than a decade, authors have discussed Holocene SWWB variability using proxy evidence from single sites located along the path of the SWWB in southern South America (e.g., Lamy et al., 2001; Jenny et al., 2002; Bertrand et al., 2005; Villa-Martínez and Moreno, 2007; Moreno et al., 2009; Sepúlveda et al., 2009). Variations in the amount of precipitation were generally interpreted as representing either latitudinal shifts or weakening/strengthening of the entire wind belt. More recently, authors have tried to refine the Holocene evolution of the SWWB in southern South America by comparing precipitation records located within the present-day core of the SWWB to records located at the northern limit of the wind belt. This approach has however led to different conclusions, with Moreno et al. (2010) arguing for a weakening of the entire SWWB during the early Holocene, and Lamy et al. (2010) proposing an expansion/contraction mechanism to resemble present-day seasonal variations.

Here, we reconstruct SWWB variability during the late Holocene using a different approach. We take advantage of the modern distribution of precipitation seasonality in the southern Andes to reconstruct variations in the latitudinal position of the SWWB. Because of the strong contrast between precipitation regimes immediately to the north (strong precipitation seasonality) and to the south (year-round precipitation) of our study site at $46^{\circ} \mathrm{S}$, relatively small latitudinal shifts of the SWWB in either direction result in large changes in precipitation seasonality. More specifically, we use inorganic geochemical measurements obtained on a sediment core from Quitralco fjord to reconstruct past changes in regional hydrology. We focus on $\mathrm{Al}, \mathrm{Ti}$, and $\mathrm{Fe}$, since data on surface samples from the fjords of northern Chilean Patagonia show that these elements are ideally suited to reconstruct past changes in hydrodynamics, i.e. in the intensity of river discharge, which is directly linked to precipitation in the Andes (Bertrand et al., 2012b). We then compare our precipitation seasonality record to regional sea surface temperature (SST) reconstructions to assess the ocean-atmosphere linkages in Patagonia during the last 1400 years.

\section{Regional settings}

\subsection{Climate}

The climate of northern Chilean Patagonia $\left(\sim 40-48^{\circ} \mathrm{S}\right)$ is clearly oceanic, temperate and hyperhumid, with freezing levels generally above $1 \mathrm{~km}$ a.s.l. (Garreaud et al., 2013). In this area, precipitation ranges from $>3000 \mathrm{~mm} / \mathrm{yr}$ on the western side of the Andes to less than $600 \mathrm{~mm} / \mathrm{yr}$ at the border with Argentina (Fig. 1a). Precipitation on the windward (western) side of the Patagonian Andes is almost entirely controlled by the SWWB and the orographic effect of the Andes (Garreaud et al., 2013). In the ocean-dominated Southern Hemisphere, the latitudinal position and strength of the SWWB is in turn mostly controlled by gradients in temperature over the Pacific and Southern Oceans, which influence the strength of the high-pressure areas of the subtropics (southeast Pacific anticyclone) and the low-pressure areas that prevail over the poles. Thus, a strong 'blocking' Pacific anticyclone can deflect the SWWB southwards, whereas high-latitude cooling and increased sea-ice around Antarctica can push the SWWB towards the equator (Bentley et al., 2009).

The present-day core of the SWWB is located at $52-53^{\circ} \mathrm{S}$ (Fig. 2). It shows very limited latitudinal variations with seasons, with a southerly position $\left(\sim 55^{\circ} \mathrm{S}\right)$ in winter when the wind belt expands, and a northerly position $\left(\sim 50^{\circ} \mathrm{S}\right)$ in summer when it contracts (Fig. 2; Garreaud et al., 2009). In austral summer (DJF), the SWWB contracts and the zonal wind speed increases (Fig. 2a). In winter (JJA), the SWWB expands in both directions and wind speed decreases (Fig. 2b, c). As a result, the region between 35 and $45^{\circ} \mathrm{S}$ is characterized by a strong precipitation seasonality, with relatively dry summers and wet winters (Fig. 1b). The duration of the dry summer season decreases southwards (see animation in Appendix 1).

Supplementary video related to this article can be found at http://dx.doi.org/10.1016/j.quascirev.2014.09.021.

In the Quitralco fjord area $\left(46^{\circ} \mathrm{S}\right)$, the climate is characterized by long but relatively mild winters (winter mean temperature: $4{ }^{\circ} \mathrm{C}$ ) and cool and short summers (summer mean temperature: $13^{\circ} \mathrm{C}$ ). The modern snowline is located at $2000 \mathrm{~m}$, and snow only occurs a few days per year at sea level (Miller, 1976). The precipitation regime at Quitralco fjord is best represented by the meteorological station at Puerto Chacabuco, which is located $60 \mathrm{~km}$ to the NE of Quitralco fjord (Fig. 1a). At Puerto Chacabuco, annual precipitation reaches $2929 \mathrm{~mm}$, and the precipitation regime is weakly seasonal, with $305 \mathrm{~mm} / \mathrm{month}$ in winter (JJA) and $188 \mathrm{~mm} / \mathrm{month}$ in summer (DJF). Large precipitation events, with precipitation rates of up to $98 \mathrm{~mm} / 24 \mathrm{~h}$ occur mostly in fall and winter. By comparison, the Puerto Marin station, which is located about $2^{\circ}$ of latitude to the north (Fig. 1a), displays similar annual precipitation values (3082 $\mathrm{mm}$ ), but a more pronounced seasonal signal, with winter precipitation ( $366 \mathrm{~mm} / \mathrm{month}$ ) being twice as high as precipitation in the summer months $(167 \mathrm{~mm} /$ month $)$. On the contrary, precipitation at Isla San Pedro, about $2^{\circ}$ of latitude to the south, shows high year-round precipitation and a lack of seasonal variability (Fig. 1a). Precipitation at Puerto Chacabuco is also strongly correlated with zonal wind speed (Garreaud et al., 2013, Appendix 2). A poleward shift of the SWWB would therefore not significantly affect annual precipitation amounts in the Quitralco area, but it would result in a significant increase in precipitation seasonality, 
a

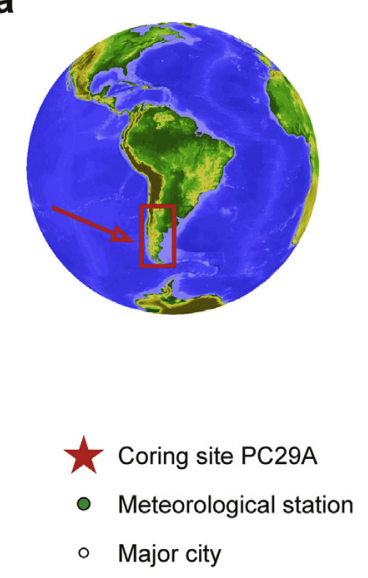

- Major city
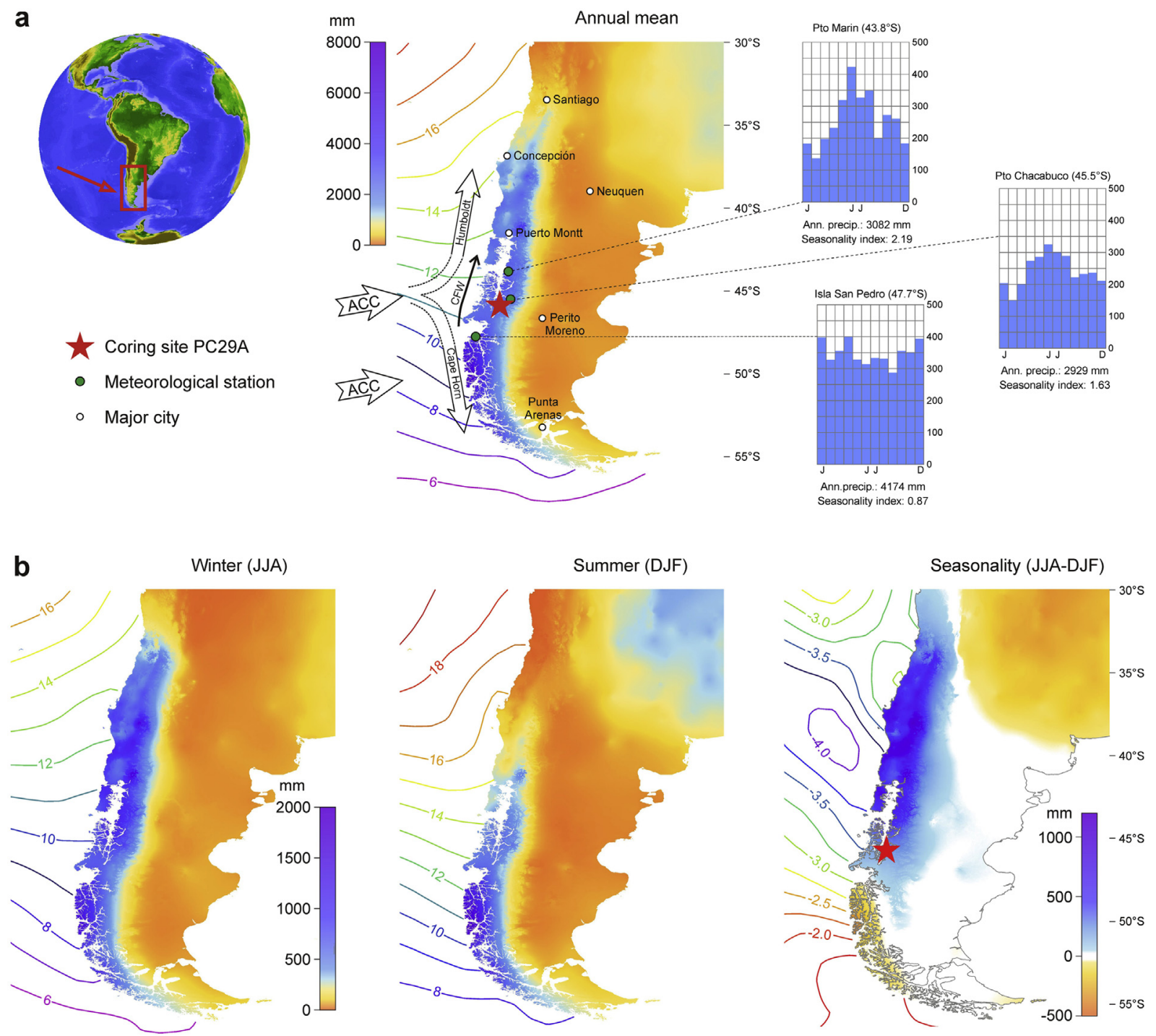

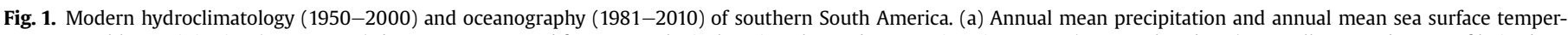

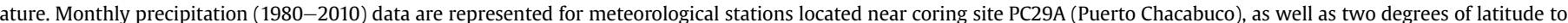

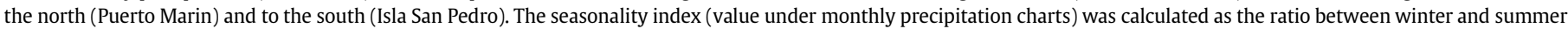

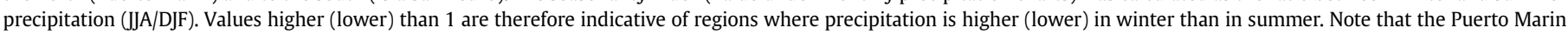

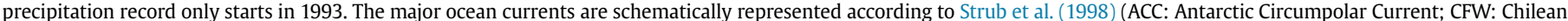

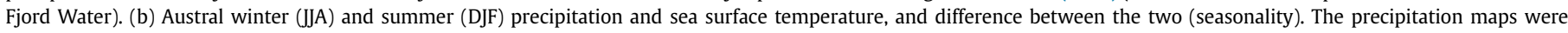

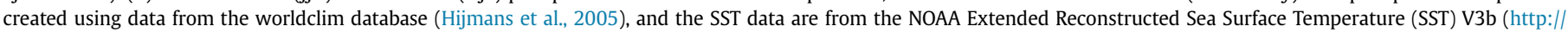
www.esrl.noaa.gov/psd/data/gridded/data.noaa.ersst.html). See appendix 1 for the animated map.

providing a precipitation regime similar to the current situation at Puerto Marin (Fig. 1a). An equatorward shift, on the other hand, would cause a decrease in precipitation seasonality.

In the last decades, global warming and the increasing ozone hole over Antarctica have caused an increase in temperature difference between the Southern Hemisphere mid- and highlatitudes, resulting in a poleward shift and contraction of the SWWB, which in turn caused a strengthening of westerly wind speeds over the Southern Ocean (Shindell and Schmidt, 2004; Toggweiler, 2009; Sen Gupta et al., 2009; Thompson et al., 2011; Garreaud et al., 2013). This recent poleward shift of the SWWB, which represents a positive phase of the SAM (Thompson et al., 2011), has caused a general decrease in annual precipitation in central and southern Chile between 35 and $50^{\circ} \mathrm{S}$ (Aravena and Luckman, 2009; Quintana and Aceituno, 2006, 2012). This trend, which is particularly marked between 37 and $43^{\circ} \mathrm{S}$ since 1950 (Quintana and Aceituno, 2012), is mostly due to a reduction in summer precipitation, resulting in an increase in precipitation seasonality over northern Chilean Patagonia. Between 1980 and 2010, precipitation seasonality on the western coast of northern Chilean Patagonia $\left(41-48^{\circ} \mathrm{S}\right)$ has increased on average by $19 \%$ (Appendix 3). Projections for the 21st century (Vera et al., 2006; Meehl et al., 2007; Appendix 4) indicate a continued decrease in annual precipitation over northern Chilean Patagonia, which is more pronounced in summer than in winter, resulting in a further increase in precipitation seasonality.

\subsection{Oceanography}

The large-scale surface circulation off southernmost Chile is dominated by the ACC, the world's largest current system (Mayewski et al., 2009), which flows uninterrupted and clockwise around Antarctica. The strength of the ACC largely depends on the latitudinal position and intensity of the SWWB. The northern part 
a

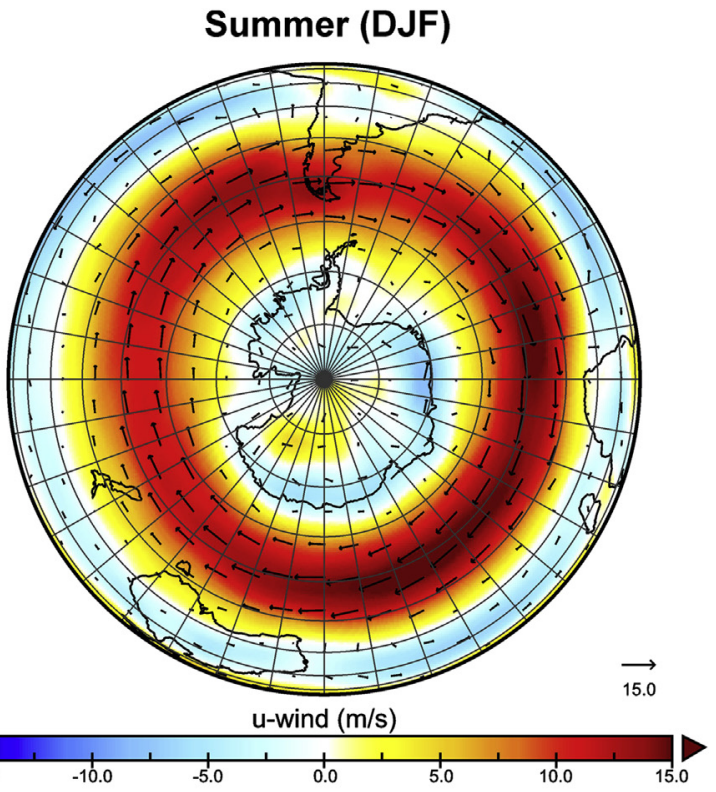

b

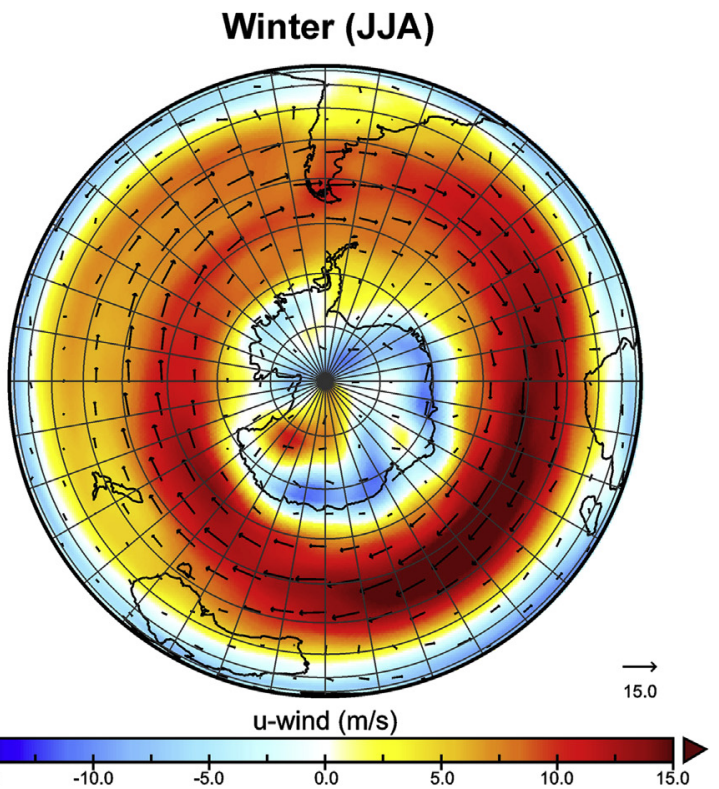

C

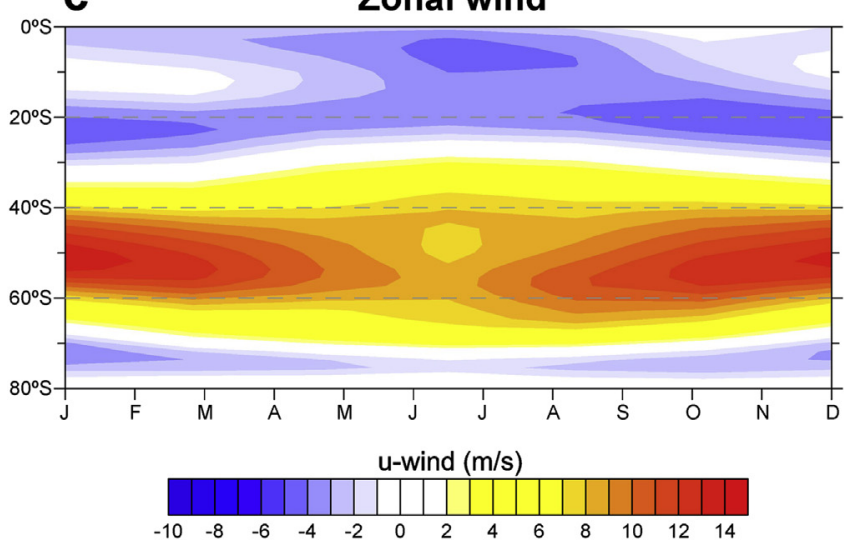

Fig. 2. Present-day climatology (1981-2010) of the Southern Hemisphere. Austral summer (a) and winter (b) wind speed and direction at $850 \mathrm{hPa}$ (NCEP/NCAR reanalysis). The color scale represents only the zonal component of wind velocity. The same of the ACC reaches the coast of southern Chile, where it splits into two coastal branches: the Cape Horn current to the south and the Humboldt, or Peru-Chile, current to the north (Fig. 1a). The Antarctic water mass flows inwards in most of the fjords between $\sim 30 \mathrm{~m}$ and $\sim 150 \mathrm{~m}$ depth (Silva and Guzmán, 2006; Sievers and Silva, 2008). It is overlain by a surface estuarine water mass (Chilean Fjord Water, CFW), which flows out of the fjords towards the Pacific Ocean between 0 and $\sim 30 \mathrm{~m}$ depth. The extension and depth of the CFW depends on the amount of freshwater supplied by rivers, glaciers, coastal runoff and direct precipitation. Along the coast of Chilean Patagonia, SST in the eastern South Pacific shows a gradual decrease poleward, with a gradient of $\sim 0.5^{\circ} \mathrm{C}$ per degree of latitude (Fig. 1). The gradient is more pronounced in summer, when the zonal systems contract.

Quitralco fjord is one of the SW-NE oriented fjords that form the fjord region of northern Chilean Patagonia (Fig. 3). It is composed of a main $\sim 15 \mathrm{~km}$ long basin that has accumulated sediment continuously throughout the Holocene (Araya-Vergara, 1997; Vieira, 2002). The bottom of the basin is slightly concave with depths between 100 and $125 \mathrm{~m}$ (Vieira, 2002; SHOA, 2004). Quitralco fjord has no major river inflow at its head but it receives significant amounts of freshwater through Rio Pelu, which drains its southern flank (Fig. 3).

\subsection{Geology}

The watershed of Rio Pelu belongs to the North Patagonian Batholith, which is composed of Cenozoic and Mesozoic granitoids (Pankhurst et al., 1999; Sernageomin, 2003). Around Quitralco fjord the batholith is dominated by hornblende-biotite tonalite (Pankhurst et al., 1999). In addition, Quitralco fjord is located near three of the thirteen Quaternary volcanoes that compose the southern segment of the southern volcanic zone (SSVZ, $42-46^{\circ} \mathrm{S}$ ): volcanoes Cay, Macá and Hudson, the latter being by far the most active (Stern et al., 2007). Due to the prevailing westerly winds and the location of Quitralco fjord to the NW of Hudson volcano, the region is only slightly affected by the eruptive products (e.g., Naranjo and Stern, 1998). The regional soil cover is dominated by thin andosols, i.e., soils developed on the Holocene volcanic ashes that reached the area (Gut, 2008; Vandekerkhove, 2014).

\subsection{Morphology and vegetation}

The watershed of Rio Pelu has a surface area of $138.7 \mathrm{~km}^{2}$, with elevations ranging from 0 to $1589 \mathrm{~m}$. The slopes within the watershed are steep, with an average of $19^{\circ}$. Most of the watershed is presently covered by a dense temperate evergreen forest (Fig. 3) mostly composed of Nothofagus betuloides and Desfontainia spinosa (Luebert and Pliscoff, 2006), reflecting the high year-round precipitation in the area. Less than $2 \%$ of the watershed is covered by glaciers (Fig. 3). River discharge is therefore mostly controlled by rainfall.

\section{Material and methods}

\subsection{Coring and sediment sampling}

Sediment core PC29A $\left(45.756^{\circ} \mathrm{S}-73.467^{\circ} \mathrm{W}\right)$ was collected at a depth of $112 \mathrm{~m}$ in Quitralco fjord during the CIMAR (Cruceros de Investigación Marina) Fiordos 7 expedition (CF7) in November

color scale was used for both figures to facilitate the comparison between summer and winter wind patterns. (c) Annual cycles of $850 \mathrm{hPa}$ zonal wind zonally averaged over the eastern Pacific $\left(75^{\circ}-90^{\circ} \mathrm{W}\right)$ in the Southern Hemisphere $\left(0-80^{\circ} \mathrm{S}\right)$. (For interpretation of the references to color in this figure legend, the reader is referred to the web version of this article.) 


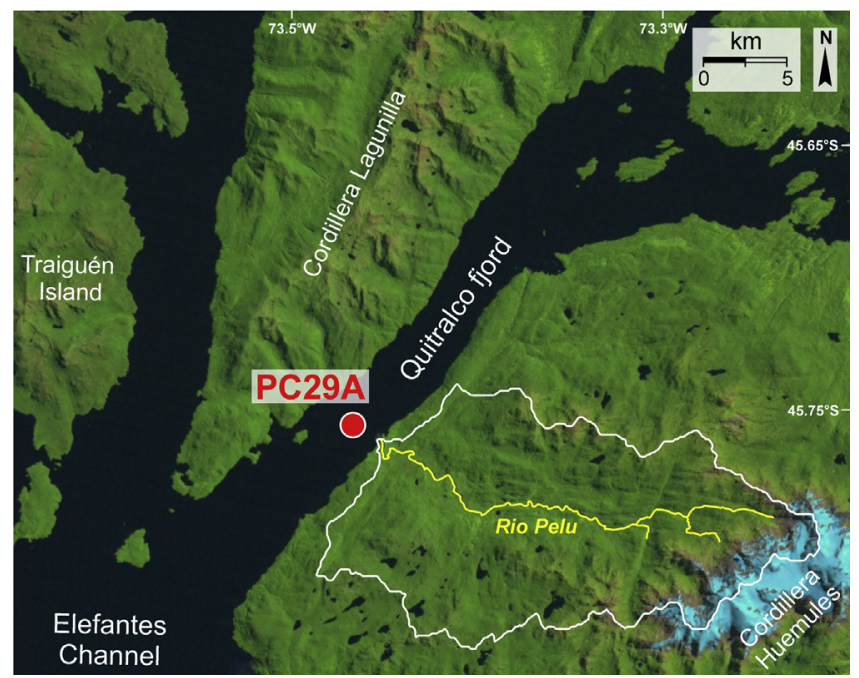

Fig. 3. Watershed (white line) of Rio Pelu represented on a natural color landsat image (LandsatLook) taken on February 11, 2011. The coring site in Quitralco fjord (PC29A) is represented by a red dot. (For interpretation of the references to color in this figure legend, the reader is referred to the web version of this article.)

2001, aboard R/V AGOR Vidal Gormáz. The coring site is located immediately in front of Rio Pelu (Fig. 3). It is therefore particularly sensitive to changes in river discharge. The $208 \mathrm{~cm}$ long piston core was split lengthwise and described at the Woods Hole Oceanographic Institution, MA, USA, where it was subsequently stored at $4{ }^{\circ} \mathrm{C}$. A complete core half was sub-sampled in $1 \mathrm{~cm}$ thick slices, which were immediately freeze-dried and ground using an agate mortar. Wet and dry sample weights were recorded for water content calculation. The archive half was used for XRF core scanning. Additionally, small ( $0.1 \mathrm{cc})$ samples were taken every $4 \mathrm{~cm}$ in the archive half for grain size analysis, and preserved wet in microcentrifuge tubes. Shell and leaf/wood remains were collected from both core halves for radiocarbon dating. These samples were cleaned with milli-Q water under a binocular lens and sent to NOSAMS for analysis. A box core (BC29A) was also collected at the same site, and sub-sampled on board in $1 \mathrm{~cm}$ thick slices.

\subsection{Age model}

The chronology of sediment core PC29A is based on seven AMS radiocarbon ages obtained on organic $(n=5)$ and inorganic $(n=2)$ macro-remains picked in the sediment core (Table 1 ). Although the upper $50 \mathrm{~cm}$ of the archive half was entirely sieved, no terrestrial macro-remain was found in that part of the core. Radiocarbon ages were calibrated with CLAM 2.2 (Blaauw, 2010), using the calibration

Table 1

Radiocarbon ages obtained on sediment core PC29A. The ages were calibrated with CLAM 2.2 (Blaauw, 2010), using the calibration curve SHCal13 (Hogg et al., 2013). A reservoir correction of 530 years was applied to the two mollusk samples.

\begin{tabular}{lllcl}
\hline $\begin{array}{l}\text { Core } \\
\text { depth } \\
(\mathrm{cm})\end{array}$ & $\begin{array}{l}\text { Laboratory } \\
\text { code }\end{array}$ & Material & ${ }^{14} \mathrm{C}(\mathrm{yr} \mathrm{BP} \pm 1 \sigma)$ & $\begin{array}{l}2 \sigma \text { calibrated } \\
\text { age range } \\
(\mathrm{min}-\mathrm{max}, \mathrm{yr} \mathrm{CE})\end{array}$ \\
\hline 17.25 & OS-38281 & Mollusk & $890 \pm 35$ & $1478-1643$ \\
75 & OS-38282 & Mollusk & $1290 \pm 30$ & $1229-1381$ \\
92.25 & OS-38359 & Plant/Wood & $910 \pm 30$ & $1048-1260$ \\
142 & OS-38360 & Plant/Wood & $1280 \pm 30$ & $685-881$ \\
185.5 & OS-53093 & Plant/Wood & $1400 \pm 30$ & $636-764$ \\
199.5 & OS-53339 & Plant/Wood & $1510 \pm 35$ & $540-647$ \\
205.5 & OS-38305 & Plant/Wood & $1430 \pm 75$ & $521-857$ \\
\hline
\end{tabular}

curve SHCal13 (Hogg et al., 2013). The reservoir age correction commonly used for the eastern South Pacific (530 years; Mohtadi et al., 2007) was applied to the two mollusk samples. In addition, a comparison between the upper part of PC29A piston core with the box core using $\delta^{13} \mathrm{C}$ values (Appendix 5) demonstrated that no sediment had been lost during the coring operation. We therefore attributed an age of 2001 to the sediment-water interface. The final age model was generated using CLAM 2.2.

\subsection{Inorganic geochemistry}

Sediment core PC29A was scanned on an ITRAX XRF core scanner (Cox Analytical Instruments) at a resolution of $1 \mathrm{~mm}$. The scanner was operated with 20 s scan times using a Mo X-Ray tube set to $30 \mathrm{kV}$ and $45 \mathrm{~mA}$. The XRF spectra were interpreted and the peak areas quantified using the Q-Spec 6.5 software.

A subset of 102 samples from core PC29A was analyzed for inorganic geochemistry by ICP-AES. Samples were prepared using the Li-metaborate (LiBr) fusion technique of Murray et al. (2000), which is preferred over HF digestion because it is the only technique that allows the complete dissolution of sediment samples containing refractory minerals such as zircon (Huang et al., 2007). Sample preparation consisted in mixing $50 \pm 0.5 \mathrm{mg}$ of sediment with $200 \pm 1.0 \mathrm{mg}$ of ultrapure Li-metaborate (SCP Science) in $3 \mathrm{ml} \mathrm{Pt}: \mathrm{Au}$ (95:5) crucibles. Ten $\mu \mathrm{l}$ of $25 \% \mathrm{LiBr}$ were then added to the mixture and the crucibles were placed in a muffle furnace for $12 \mathrm{~min}$ at $1050^{\circ} \mathrm{C}$. The newly formed glass beads were then allowed to cool down for 2-3 min, detached from the crucible, and poured into a Teflon beaker containing a swirling $25 \mathrm{ml}$ solution of $5 \%$ $\mathrm{HNO}_{3}$. Complete dissolution occurred within $\sim 30 \mathrm{~min}$. The solution was then filtered through a $0.45 \mu \mathrm{m}$ PVDF Millipore filter and diluted in $5 \% \mathrm{HNO}_{3}$ to obtain a $4000 \times$ final dilution of the sample. The exact dilution factor was calculated from the precise weight of sediment used for fusion.

Thirteen elements were measured on a JY Ultima C ICP-AES. Analytical details are given in Bertrand et al. (2012b). Here, we focus on the lithophile and mostly immobile elements $\mathrm{Fe}, \mathrm{Ti}$, and $\mathrm{Al}$, to reconstruct changes in hydrodynamic conditions following Bertrand et al. (2012b), as well as Si. Analytical precision $(1 \sigma)$, which was calculated from the analysis of ten individuallyprepared sub-samples of reference sediment PACS-2, is $0.66 \%$ for $\mathrm{Al}, 0.71 \%$ for $\mathrm{Fe}, 1.03 \%$ for $\mathrm{Ti}$, and $0.68 \%$ for $\mathrm{Si}$. Precision for the elemental ratios $\mathrm{Fe} / \mathrm{Al}$ and $\mathrm{Ti} / \mathrm{Al}$ is $0.66 \%$ and $0.68 \%$, respectively.

\subsection{Mineralogy}

The bulk mineralogy of the same 102 samples was analyzed by X-ray diffraction (XRD) on a Bruker D8-Advance diffractometer with $\mathrm{CuK} \alpha$ radiation. Samples were mounted as unoriented powder using the back-side method (Brindley and Brown, 1980), and subsequently scanned by XRD between $2^{\circ}$ and $45^{\circ} 2 \theta$. Peak intensities were used to quantify ( $\pm 5 \mathrm{wt}$. \%) the mineral proportions, following Cook et al. (1975). Clay minerals were not identified or quantified on the bulk diffractograms. Although halite was detected in all the sediment samples, it was not quantified because it derives from interstitial water salts that precipitated during freeze-drying.

\subsection{Bulk organic geochemistry}

Approximately $50 \mathrm{mg}$ of ground sediment was weighed in tin capsules and treated with $1 \mathrm{~N}$ sulphurous acid to remove eventual carbonates (Verardo et al., 1990). Total Organic Carbon (TOC), Total Nitrogen (TN) and stable isotope ratios of carbon $\left(\delta^{13} \mathrm{C}\right)$ were measured at the UCDavis Stable Isotope Facility by continuous flow isotope ratio mass spectrometry (CF-IRMS; 20-20 SERCON mass 
spectrometer) after sample combustion to $\mathrm{CO}_{2}$ and $\mathrm{N}_{2}$ at $1000{ }^{\circ} \mathrm{C}$ in an on-line elemental analyzer (PDZEuropa ANCA-GSL). The precision, calculated by replicate analysis of the internal standard, is $0.04 \%$ for $\delta^{13} \mathrm{C}$.

\subsection{Carbonate content}

The weight percentage of total inorganic carbon (TIC) in bulk sediment samples was determined every $5 \mathrm{~cm}$ using a UIC CM5014 coulometer equipped with a CM5130 acidification module. For each sample, 50-60 mg of sediment was precisely weighed in a $4 \mathrm{ml}$ glass vial and treated with $1.5 \mathrm{ml} 1 \mathrm{~N} \mathrm{H}_{3} \mathrm{PO}_{4}$ to liberate $\mathrm{CO}_{2}$. The percentage of carbonate was calculated from the TIC data using the following equation: $\mathrm{CaCO}_{3}(\mathrm{wt} \%)=\mathrm{TIC}(\mathrm{wt} \%) \times 8.33$, assuming that $100 \%$ of the measured $\mathrm{CO}_{2}$ is derived from dissolution of calcium carbonate. The analytical precision, determined from 7 entirely separate analyses of a sediment sample from site PC29A, was $0.04 \%$ $\mathrm{CaCO}_{3}$.

\subsection{Biogenic opal}

Biogenic silica (bio-Si) was analyzed according to Carter and Colman (1994) and Mortlock and Froelich (1989). Samples were extracted with $\mathrm{NaOH}$ after removal of organic matter and carbonate with $10 \% \mathrm{H}_{2} \mathrm{O}_{2}$ and $1 \mathrm{~N} \mathrm{HCl}$, respectively. They were subsequently diluted in 5\% nitric acid and analyzed in triplicate for Si and Fe on a JY Ultima-C ICP-AES. Al was measured in triplicate by flame atomic absorption spectrometry (FAAS) on a Varian SpectrAA 22. Measured Si concentrations were corrected for detrital Si using the measured Al concentrations: bio- $\mathrm{Si}=$ measured $\mathrm{Si}-2 \times \mathrm{Al}$. The 2:1 ratio accounts for Si leached from volcanic glasses and clay minerals. This correction assumes that all $\mathrm{Al}$ originates from the dissolution of detrital particles. The precision on bio-Si, determined from 5 entirely separate analyses of a sediment sample from site PC29A, was $0.46 \%$. Biogenic opal (bio-opal, $\mathrm{SiO}_{2} \cdot n \mathrm{H}_{2} \mathrm{O}$, wt. \%) was obtained by multiplying the bio-Si values by 2.4 (Mortlock and Froelich, 1989). Lithogenic silica (litho-Si, wt. \%) was calculated by difference (Total Si [see 3.3] - bio-Si).

\subsection{Grain-size}

Grain-size was measured on the terrigenous fraction of the sediment using a Coulter LS200 laser grain-size analyzer. The terrigenous fraction was isolated by treating the samples with boiling $\mathrm{H}_{2} \mathrm{O}_{2}, \mathrm{HCl}$ and $\mathrm{NaOH}$, to remove organic matter, carbonates and biogenic silica, respectively. Prior to analysis, samples were boiled with $300 \mathrm{mg}$ of sodium pyrophosphate $\left(\mathrm{Na}_{4} \mathrm{P}_{2} \mathrm{O}_{7} \cdot 10 \mathrm{H}_{2} \mathrm{O}\right)$ to ensure complete disaggregation of the particles. The grain-size distribution of the samples was measured during $90 \mathrm{~s}$ and the arithmetic mean was calculated from the 92 size classes. Downcore grain-size distributions were unmixed using the end-member modeling algorithm of Weltje and Prins (2007).

\section{Results}

\subsection{Lithology}

Sediment core PC29A is composed of grayish olive (5Y 4/2) homogenous mud. No sedimentary structures or tephra layers were visible macroscopically but abundant small organic matter debris were observed between 208 and $169 \mathrm{~cm}$. The sediment is composed of lithogenic particles $(84.0 \pm 0.7 \mathrm{wt}$. \%; calculated as $100 \%$ - bio-opal $-2.2 \times$ TOC $-\mathrm{CaCO}_{3}$; Bertrand et al., 2012b), biogenic opal (13.2 $\pm 0.8 \mathrm{wt}$ \% $)$, organic matter $(2.78 \pm 0.36 \mathrm{wt}$. \%; calculated as $2.2 \times \mathrm{TOC})$, and very little carbonate $(0.05 \pm 0.03 \mathrm{wt}$. $\%$ ) (average \pm 1 s.d.). Downcore plots (Fig. 4) clearly show a continuous increase in biogenic opal towards the top of the core and a decrease in TOC in the upper $65 \mathrm{~cm}$, resulting in only very minor variations in the lithogenic content of the sediment (Fig. 4). According to the $\delta^{13} \mathrm{C}$ values, roughly half of the organic carbon is of terrestrial origin (Appendix 5).

\subsection{Chronology}

The final CLAM age model of core PC29A consists in a smooth spline (smooth factor 0.35) fitting through the probability distributions of the calibrated radiocarbon ages (Fig. 5). A smooth spline

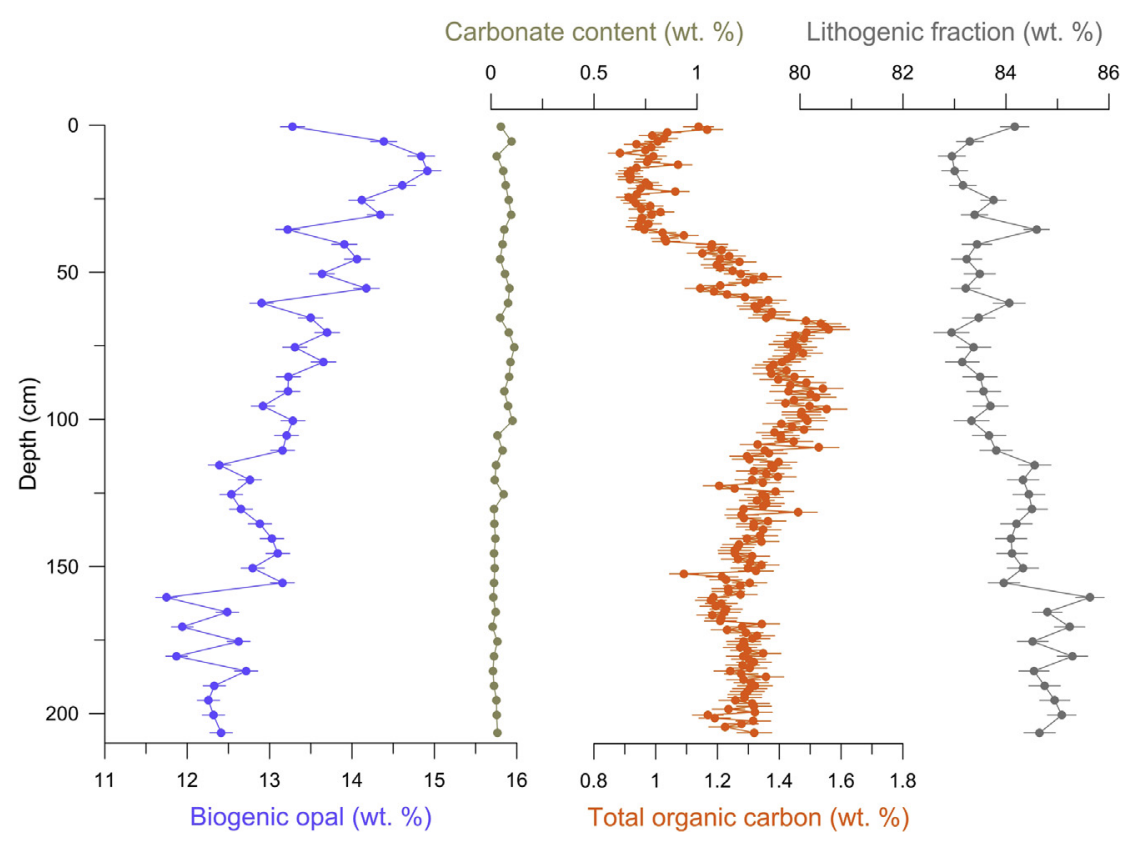

Fig. 4. Composition of sediment core PC29A. The four sediment components are expressed in weight percent of dry sediment. Error bars correspond to 1 sigma. 


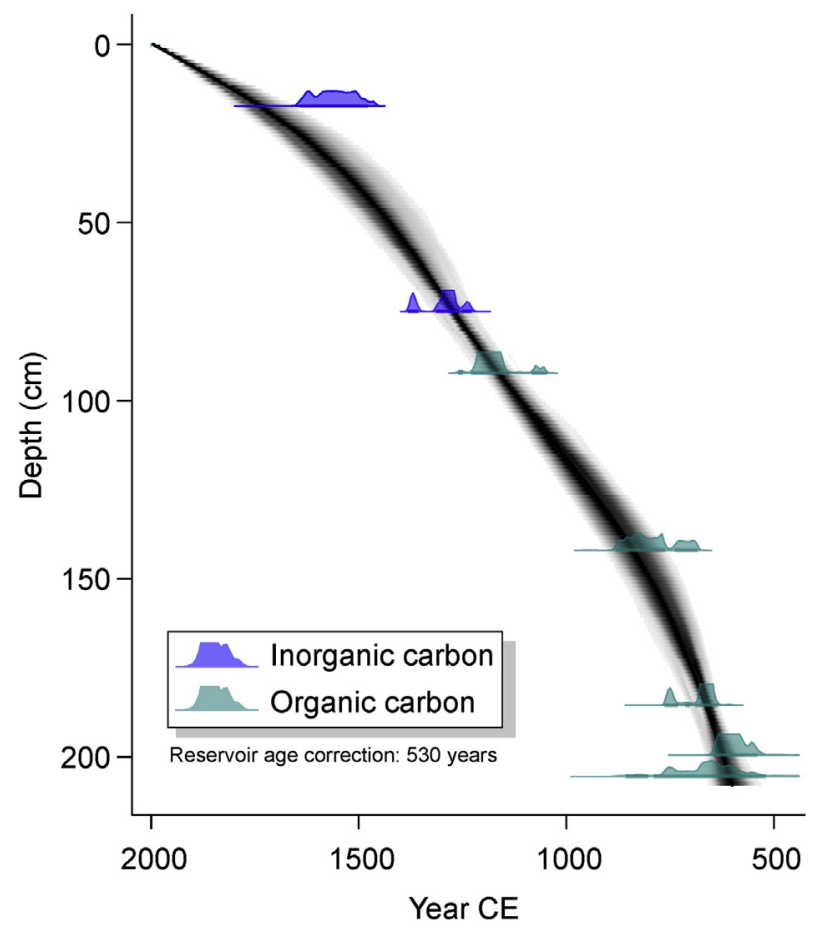

Fig. 5. CLAM age model of sediment core PC29A. The gray levels represent the density of probability (bayesian age-depth modeling).

is preferred over linear regressions since there are no visible features in the sediment core that indicate abrupt changes in accumulation rates. The bottom of the core $(208 \mathrm{~cm})$ is dated at $605 \mathrm{CE}$ (95\% confidence interval: 556-656 CE). Sedimentation rates range from $3.7 \mathrm{~mm} / \mathrm{yr}$ at the bottom of the core to $0.6 \mathrm{~mm} / \mathrm{yr}$ in the upper centimeter.

\subsection{Inorganic geochemistry}

The XRF core scanner data show significant increases in $\mathrm{Fe}$ and Ti in the upper $\sim 50 \mathrm{~cm}$ of the sediment core, with a return to lower values in the top $23 \mathrm{~mm}$ (Fig. 6). The ICP-AES measurements show very similar trends for both elements, resulting in high correlations between XRF and ICP measurements $(r=0.85, p<0.001$ for Fe and $r=0.92, p<0.001$ for $\mathrm{Ti}$ ). Al concentrations are mostly constant throughout the core $(7.80 \pm 0.13$ wt. \%), reflecting the constant lithogenic content of the sediment (Fig. 4). Fe and Ti XRF counts are therefore also highly correlated to $\mathrm{Fe} / \mathrm{Al}(r=0.88, p<0.001)$ and Ti/ $\mathrm{Al}(r=0.93, p<0.001)$.

\subsection{Grain-size and mineralogy}

The grain-size of the terrigenous fraction of the sediment shows high values in the lowermost part of the core (average of $29.8 \mu \mathrm{m}$ below $168 \mathrm{~cm}$ ), slightly lower values between 168 and $60 \mathrm{~cm}$ (average: $27.2 \mu \mathrm{m}$ ), and then a constant decrease down to $17.4 \mu \mathrm{m}$ towards the top (Fig. 6). Most of the grain-size distribution plots are bimodal, with a fine mode at $5.6 \mu \mathrm{m}$ and a coarse mode at $30 \mu \mathrm{m}$ (Appendix 6). A two end-member model, which explains $67 \%$ of the variance of the total set of grain-size distributions, was therefore selected. Both end-members co-exist in most of the core but the coarse end-member is heavily reduced in its upper part (Appendix 6).

The bulk mineralogical composition of sediment core PC29A (average \pm 1 s.d.) is dominated by plagioclase ( $43 \pm 6 \%$ ), K-feldspar $(19 \pm 4 \%)$, amphibole $(14 \pm 3 \%)$, pyroxene $(11 \pm 3 \%)$ and quartz $(10 \pm 3 \%)$, reflecting a mixture of volcanic (andosol) and granodioritic sources. The quartz content of the sediment is high and rather constant below $52 \mathrm{~cm}(12 \pm 3 \%)$, and much lower $(7 \pm 2 \%)$ above (Fig. 6). Both grain-size and quartz display significant positive correlations with litho-Si/Al $(r=0.82, p<0.01$ and $r=0.55$, $p=0.01$, respectively).

\section{Interpretation and discussion}

\subsection{Controls on sediment composition}

In modern sediments from the fjords of northern Chilean Patagonia, Al concentrations faithfully reflect the proportion of lithogenic particles in the sediment. Because $\mathrm{Al}$ is a primary constituent of most aluminosilicate minerals, $\mathrm{Al}$ concentrations in the lithogenic fractions of Chilean fjord sediments are mostly independent of changes in mineralogy and/or grain-size (Bertrand et al., 2012b). This statement also applies to sediment core PC29A, which

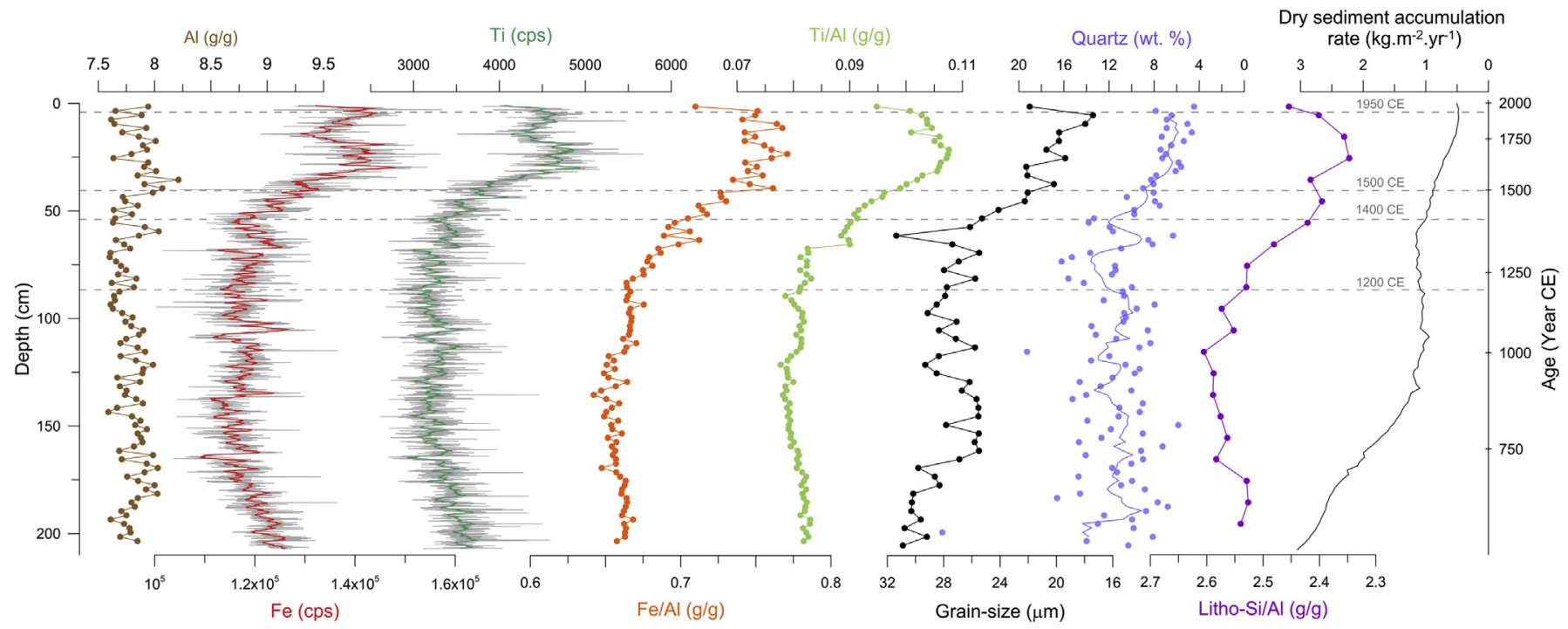

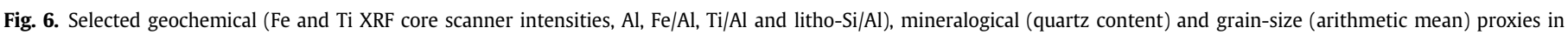
sediment core PC29A. The sediment accumulation rates were computed from the age model presented in Fig. 5. 
shows very little downcore variations in the lithogenic content of the sediment (Fig. 4) and Al concentrations (Fig. 6). Al concentrations in the lithogenic fraction of the sediment are $9.33 \pm 0.18 \%$, in agreement with a mixture of granodioritic bedrock $(8.16 \pm 1.16 \%)$ and volcanic ash soil $(10.45 \pm 1.50 \%)$ sources (Bertrand et al., 2012b). Al is therefore the ideal lithogenic geochemical element to normalize other geochemical elements to in order to assess changes in the lithogenic fraction of the sediment.

Since Al concentrations in core PC29A are roughly constant downcore, variations in the concentrations of other lithogenic elements, such as the Fe and Ti (Fig. 6), mostly reflect variations in the composition of the lithogenic fraction of the sediment and are not due to dilution by other sediment components. This is confirmed by the downcore trends in $\mathrm{Fe} / \mathrm{Al}$ and $\mathrm{Ti} / \mathrm{Al}$, which are highly positively correlated to the Fe and Ti XRF core scanner counts (Fig. 6).

In sediment records from terrestrial and near-shore environments, increases in lithogenic elements $\mathrm{Fe}$ and $\mathrm{Ti}$ are commonly interpreted as increases in terrestrial supply, which are in turn interpreted as increased precipitation (e.g., Haug et al., 2001; Lamy et al., 2004). Following this classical interpretation, the upper part of sediment core PC29A would be interpreted as representing a higher terrestrial supply of particles, and therefore more precipitation. However, the same upper part of the sediment core shows a significant decrease in grain-size, reflecting a decrease in the energy of river discharge (Fig. 6). This decrease in grain-size is also supported by the decrease in quartz and litho-Si/Al, since quartz is always enriched in the coarse fraction of North Patagonian fjord sediments (Bertrand et al., 2012b). Increases in Fe and Ti therefore represent a decrease in hydrodynamic conditions, in agreement with the data obtained on river-proximal fjord surface sediment samples (Bertrand et al., 2012b). In these environments, increasing hydrodynamic conditions are recorded as higher concentrations of coarse and refractory minerals, such as quartz, which dilute Fe and Ti-bearing minerals, and are ultimately represented by the decrease of Fe and Ti concentrations (Bertrand et al., 2012b). Although Fe variations alone could be attributed to redox changes in the sediment, $\mathrm{Ti}$ is insensitive to environmental redox variations. The excellent match between Fe and Ti concentrations in core PC29A $(r=0.98, p<0.0001)$ provides evidence that these elements are not controlled by diagenetic processes and that either element reflects changes in the composition of the lithogenic fraction of the sediment. In core PC29A, grain-size is therefore the single most important parameter that controls downcore variations in mineralogy and inorganic geochemistry (lithogenic elements).

\subsection{Paleohydrological interpretation}

The sediment deposited at coring site PC29A mostly originates from the settling of particles transported in suspension in Rio Pelu (Fig. 3). Numerous processes can affect the particle size distribution of suspended sediments in river systems (Walling and Moorehead, 1989; Walling et al., 2000). For small mountain rivers, it appears that the size of particles transported in suspension is mostly driven by changes in river discharge, and can therefore be used to reconstruct flood intensity (Reid and Frostick, 1994; Lenzi and Marchi, 2000; Grangeon et al., 2012). As a result sediment records in river-proximal environments, mostly lakes, are frequently used to reconstruct the intensity of past flood events (Campbell, 1998), which are in turn interpreted in terms of rainfall intensity/storminess (Noren et al., 2002; Parris et al., 2010; Giguet-Covex et al., 2012) or snow melt intensity (nival freshet; Kaufman et al., 2011).

Additional studies highlight the importance of precipitation seasonality in controlling the grain-size and yield of suspended sediment in modern river systems because (1) vegetation density, and therefore soil stability, decreases with increasing precipitation seasonality; (2) intense seasonal rainfall results in more runoff than continuous rainfall because of the limited time for water infiltration; and (3) the rate of soil erosion increases exponentially with runoff (Milliman, 1997; Hooke, 2000; Guerra and Soares Da Silva, 2011). This is also in agreement with Kaufman et al. (2011), who demonstrated that the grain-size of river-proximal lake sediments is strongly correlated to maximum spring daily discharge, and not to annual discharge.

Following these considerations, we interpret increases in sediment grain-size, and therefore decreasing Fe and Ti concentrations, at site PC29A as representing more intense seasonal floods of Rio Pelu, which are in turn interpreted as increased precipitation seasonality. The steep slopes that characterize the watershed of Rio Pelu make it particularly susceptible to soil erosion, and therefore sensitive to changes in precipitation seasonality. Although floods can also be triggered by rapid snow and/or ice melt, we believe that this process is negligible in the region of Quitralco fjord because (1) less than $2 \%$ of the watershed of Rio Pelu is currently covered by glaciers, and (2) the oceanic climate favors rainfall over snowfall. It must also have remained negligible during the last 1400 years, as indicated by the lack of glacigenic characteristics of the sediment throughout the core (Appendix 5). It should also be noted that there is no evidence of recent or past anthropogenic activities in the watershed of Rio Pelu. Soil erosion therefore only reflects natural processes.

With this in mind, downcore changes in $\mathrm{Fe} / \mathrm{Al}$, Ti/Al and grain-size (Fig. 6) can be interpreted in terms of changes in precipitation seasonality in northern Chilean Patagonia. The record can be subdivided in three major periods (Fig. 6): 600-1200 CE, which is characterized by a strong precipitation seasonality; 1200-1500 CE, with a gradual decrease in precipitation seasonality that accelerates at $1400 \mathrm{CE}$; and 1500-1950 CE, during which precipitation seasonality is the lowest (Fig. 6). After 1950 CE, most proxies display a return to increased precipitation seasonality, in agreement with recent trends observed in instrumental data from northern Chilean Patagonia (Appendix 3). Our interpretation of the PC29A sediment record in terms of flood intensity and precipitation seasonality is further supported by (1) the concomitant variations in accumulation rates, which reflect river sediment yield, and sediment grain-size (Fig. 6), and (2) the increase in $\delta^{13} \mathrm{C}$ values (Appendix 5) and the absence of macroscopical organic remains, which both reflect weaker soil erosion, in the upper, i.e., less seasonal, part of the record.

\subsection{Precipitation seasonality and the southern westerlies}

The late Holocene changes in precipitation seasonality reconstructed from sediment core PC29A can be interpreted in terms of latitudinal variations of the SWWB, using the modern latitudinal distribution of precipitation seasonality over Chilean Patagonia (Fig. 1) as an analog. The PC29A record displays high precipitation seasonality between 600 and 1200 CE. Such a high seasonality likely reflects a more poleward position of the SWWB, resulting in a precipitation regime around Quitralco fjord similar to the presentday conditions at $43-44^{\circ} \mathrm{S}$ (see Puerto Marin meteorological station in Fig. 1), i.e., a poleward shift of the SSWB of $\sim 2^{\circ}$ compared to its present-day location. Following the same reasoning, the gradual decrease in precipitation seasonality between 1200 and $1500 \mathrm{CE}$, followed by a very weak or no seasonality in precipitation between 1500 and $1950 \mathrm{CE}$, is thought to represent a gradual equatorward shift of the SWWB. This resulted in a precipitation regime in 1500-1950 CE over Quitralco fjord similar to the present-day conditions found at $47-48^{\circ} \mathrm{S}$ (see Isla San Pedro meteorological station in Fig. 1). The return to slightly more seasonal precipitation conditions during the last 50 years likely results from the recent poleward shift of the SWWB (Shindell and Schmidt, 2004; Appendix 3). By comparison with modern precipitation regimes, 
the amplitude of the latitudinal shift of the SWWB during the last 1400 years can be estimated at about $3-4^{\circ}$ of latitude. Although our precipitation seasonality reconstruction is in good agreement with the recent increase in precipitation seasonality in northern Chilean Patagonia, it is in contradiction with the gridded reconstruction of Neukom et al. (2010), which shows that precipitation seasonality in Chilean Patagonia in 1931-1995 was lower than during any of the four previous centuries. This apparent discrepancy is mostly likely caused by the low amount of records from the windward side of the Patagonian Andes in Neukom's reconstruction, which resulted in the over-extrapolation of records located on the lee side of the Andes.

\subsection{Comparison with other precipitation/SWWB records}

The timing of the decrease in precipitation seasonality recorded in core PC29A at $1200-1500$ CE roughly corresponds to a major reorganization of the climate system throughout the world, which is frequently associated to the Little Ice Age originally described in the Northern Hemisphere. Here, we compare the PC29A record to regional precipitation and SWWB reconstructions. We focus on records that (1) cover at least the same duration, and (2) reconstruct variability at multi-decadal to multi-centennial timescales. Although many tree-ring reconstructions exist in the region, these records were not included in our comparison since they only cover the last centuries and, most importantly, they are known to underestimate multi-centennial variability because of uncertainties in detrending (Esper et al., 2004; Marcott et al., 2013). In south-central Chile (34-41 ${ }^{\circ}$ ), several precipitation reconstructions show an increase in precipitation and therefore in westerly wind speed (cf Garreaud et al., 2013) during the last millennium (Fig. 7). The Laguna Aculeo record, which is located close to the present-day northern limit of the SWWB in winter $\left(34^{\circ} \mathrm{S}\right)$ shows an increase in clastic layers, interpreted as representing increasing river floods in 1200-1800 CE (Jenny et al., 2002; Fig. 7a). Similarly, the pollen record of Laguna San Pedro $\left(38^{\circ} \mathrm{S}\right)$ reveals an increase in the Nothofagus/Poaceae index, reflecting more humid conditions, between 1200 and 1850 CE (Fletcher and Moreno, 2012; Fig. 7b). Two records located at $40^{\circ} \mathrm{S}$ display a similar increase in precipitation of westerly origin during the 15 th to 18 th centuries. In Puyehue lake, Bertrand et al. (2005) show increased accumulation rates of terrigenous particles, interpreted as higher river discharge resulting from increased precipitation in 1470-1755 CE (Fig. 7c). Similarly, the marine sediment record GeoB3313-1 (41 ${ }^{\circ} \mathrm{S}$ ) of Lamy et al. (2001) provides evidence for increased precipitation in 1375-1750 CE, in addition to a previous minor increase in 600-750 CE (Fig. 7d). A similar increase in precipitation of westerly origin after $1200 \mathrm{CE}$ was also interpreted from organic geochemical proxies in Jacaf fjord sediments at $44^{\circ} \mathrm{S}$ (Sepúlveda et al., 2009). Finally, the low resolution pollen record at Alerce $\left(41^{\circ} \mathrm{S}\right)$ indicates high precipitation, and therefore strengthening of the westerlies, between 1500 and 1850 CE (Heusser and Streeter, 1980). Together, these records provide evidence for increased precipitation in south-central Chile $\left(34-41^{\circ} \mathrm{S}\right)$ starting in $1200-1500 \mathrm{CE}$ and ending in 1750-1850 CE.

In southern Chilean Patagonia $\left(>50^{\circ} \mathrm{S}\right)$, the pollen record of Lago Guanaco in Torres del Paine $\left(51^{\circ} \mathrm{S}\right)$, reveals an increase in the Nothofagus/Poaceae index (NPI) between 1500 and 1900 CE (Fig. 7f), which, based on the present-day positive correlation between westerly wind speed and precipitation at Torres del Paine, was originally interpreted as representing stronger SWWB (Moreno et al., 2010). This interpretation was however challenged by Lamy et al. (2010) and Kilian and Lamy (2012), who argue that because of the location of Torres del Paine on the lee side of the Andes, increases in the NPI index may actually represent weaker

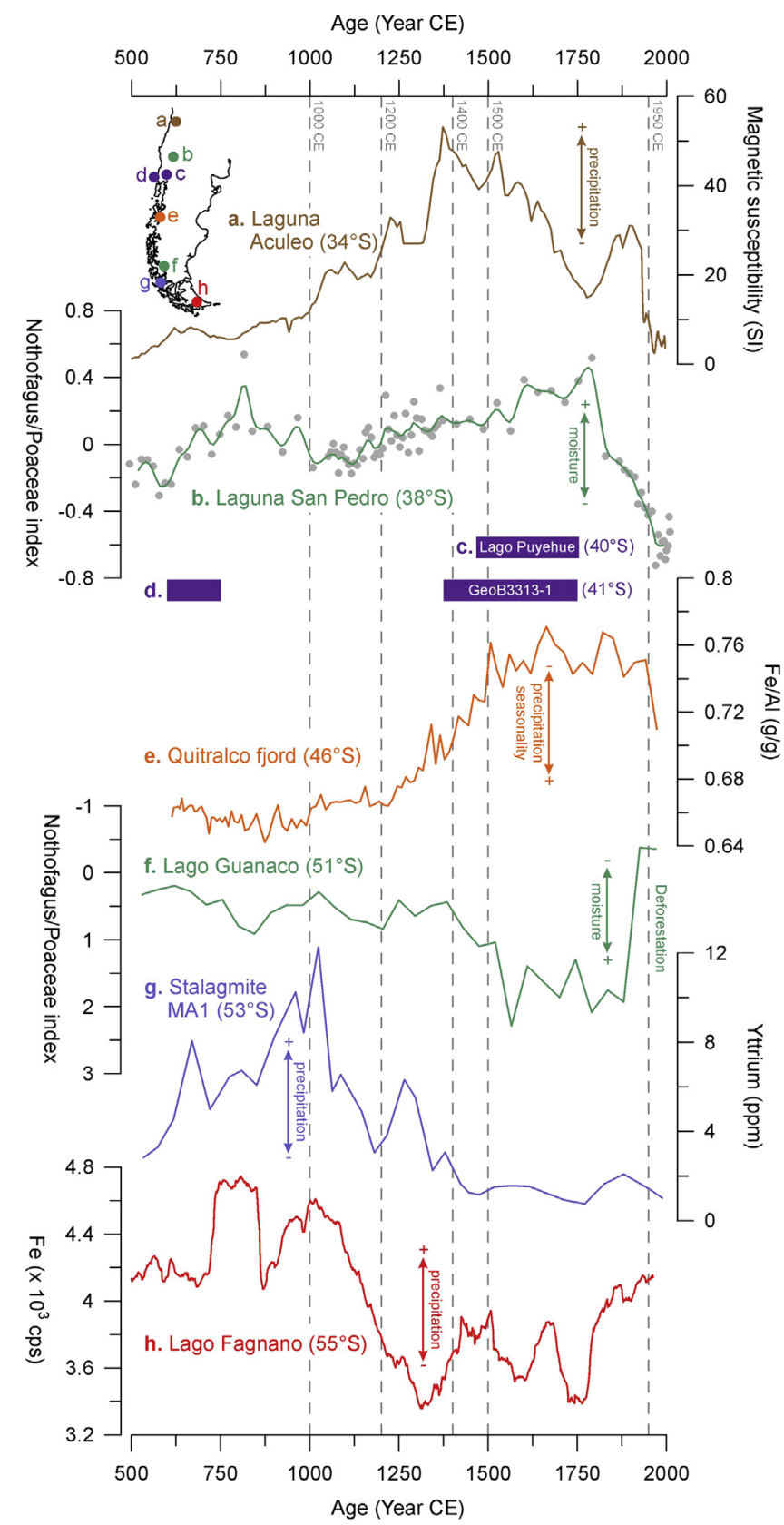

Fig. 7. Selected paleoclimate and paleoenvironmental records from the Southern Hemisphere and comparison with the PC29A precipitation seasonality record. (a) Magnetic susceptibility of Laguna Aculeo (Jenny et al., 2002). High MS values represent flood layers. (b) Nothofagus/Poaceae index of Laguna San Pedro (Fletcher and Moreno, 2012). The green line corresponds to the 50-yr running average. (c) Highest accumulation rates of terrigenous particles in Lago Puyehue (Bertrand et al., 2005). (d) High precipitation periods derived from the iron content of sediment core GeoB3313-3 (Lamy et al., 2001). (e) Fe/Al of core PC29A (this study). (f) Lago Guanaco Nothofagus/Poaceae index (Moreno et al., 2010). (g) Yttrium concentration in stalagmite MA1 (Schimpf et al., 2011). (h) Iron content in Lago Fagnano (Waldmann et al., 2010). Iron values corresponding to turbidites were removed from the dataset. The core chronology is from Waldmann et al. (2014). The records are presented from north to south, and all proxies are plotted such as wind strength increases towards the top of the figure. See Section 5.4 for interpretation of the individual records. (For interpretation of the references to color in this figure legend, the reader is referred to the web version of this article.)

westerly winds. The latter interpretation seems to be in agreement with the lake level reconstruction of Laguna Potrok Aike. In this lake, which is located at $52^{\circ} \mathrm{S}$ in Argentinean Patagonia where precipitation is negatively correlated with westerly wind strength, 
Haberzettl et al. (2005) identified a period of increased lake level, and therefore wetter conditions related to a decrease in the strength of the SWWB in 1460-1940 CE. Further south, the MA1 stalagmite record $\left(53^{\circ} \mathrm{S}\right)$ also provides evidence for a decrease in annual precipitation, and therefore a weakening of the westerlies, between 1400 CE and the present (Schimpf et al., 2011, Fig. 7g). Similarly, the sediment record from Lago Fagnano (Waldmann et al., 2010; Fig. 7h) suggests a decrease in precipitation of westerly origin, represented by a decrease in iron supply, in 1200-1850 CE. Although the Holocene lake and fjord sediment records of Lamy et al. (2010) cover the same region between 51 and $54^{\circ} \mathrm{S}$, these records do not show significant changes in precipitation during the last millennium, possibly due to their location in the core of the SWWB. Because of the constantly high wind speeds that occur in the core of the wind belt $\left(50-55^{\circ} \mathrm{S}\right.$; Fig. 2$)$, small variations in the latitudinal position of the SWWB (i.e., $1-2^{\circ}$ ), do likely not result in significant changes in precipitation at $51-54^{\circ} \mathrm{S}$. This makes this region relatively insensitive to low amplitude latitudinal shifts of the SWWB, despite the high and positive correlation between precipitation and westerly wind speed.

Although there is currently no straightforward record of late Holocene westerly wind speed variations from the Antarctic Peninsula (e.g., Bentley et al., 2009), Koffman et al. (2013) used changes in the grain-size of dust particles in the WAIS Divide ice core to show that westerly wind speed at the southern boundary of the SWWB decreased in 1400-1850 CE. Other Antarctic ice core records have been used to infer past changes in wind strength but these records are mostly based on the sea-salt sodium proxy, which is influenced by multiple parameters, such as atmospheric circulation and sea-ice cover, and can therefore not be unambiguously interpreted as variations in westerly wind speed (Koffman et al., 2013).

In summary, the interpretation of our Quitralco fjord sediment record in terms of latitudinal shifts of the SWWB during the last 1400 years is supported by most existing records from south-central and southern Chile. Low precipitation in south-central Chile (Fig. $7 \mathrm{a}-\mathrm{d}$ ) and high precipitation in southern Patagonia (Fig. $7 \mathrm{f}-\mathrm{h}$ ) in 600-1000 CE agree with a southward position of the SSWB, as reflected in sediment core PC29A (Fig. 7e). Similarly, the northward shift of the SWWB that was identified from sediment core PC29A in $1200-1950$ CE is supported by higher precipitation in south-central Chile in 1200-1800 CE (Lamy et al., 2001; Jenny et al., 2002; Bertrand et al., 2005; Fletcher and Moreno, 2012), lower precipitation at the southwestern tip of Patagonia in 1200-1850 CE (Moreno et al., 2010; Waldmann et al., 2010; Schimpf et al., 2011), and by the decrease in westerly wind speed over West Antarctica identified by Koffman et al. (2013). These records collectively provide evidence for a more southward location of the SWWB in 600-1000 CE, a northward shift in 1200-1500 CE and a sustained northward position in 1500-1900 CE. We cannot totally reject the hypothesis that the northward migration of the SWWB in 1200-1900 CE was accompanied by an expansion of the northern half of SWWB, which could explain the nearly simultaneous increase in precipitation over a large latitudinal range (e.g., $34^{\circ}-41^{\circ} \mathrm{S}$ ). Contraction/expansion of the SWWB alone can however not explain the precipitation seasonality changes observed at site PC29A. To refine this interpretation and discuss the potential accompanying expansion/contraction of the SWWB, additional westerly wind speed records from the southern limit of the SWWB, i.e., the Antarctica Peninsula, are critically needed.

\subsection{Comparison with sea surface temperature records}

In the present-day environment, the seasonal contraction (expansion) of the SWWB in summer (winter) is associated with an increase (decrease) in SST gradient (Figs. 1 and 2). This differs from glacial-interglacial timescales, for which models and paleoclimate reconstructions show that the SWWB migrated equatorward during glacials and shifted poleward during interglacials (Toggweiler et al., 2006; Kohfeld et al., 2013), although not all models agree (Sime et al., 2013). To assess the relation between changes in the latitudinal position of the SWWB and variations in SST during the late Holocene, we compare our PC29A precipitation seasonality record to existing SST records from the southeastern Pacific, Chilean fjord region and Antarctic Peninsula (Fig. 8).

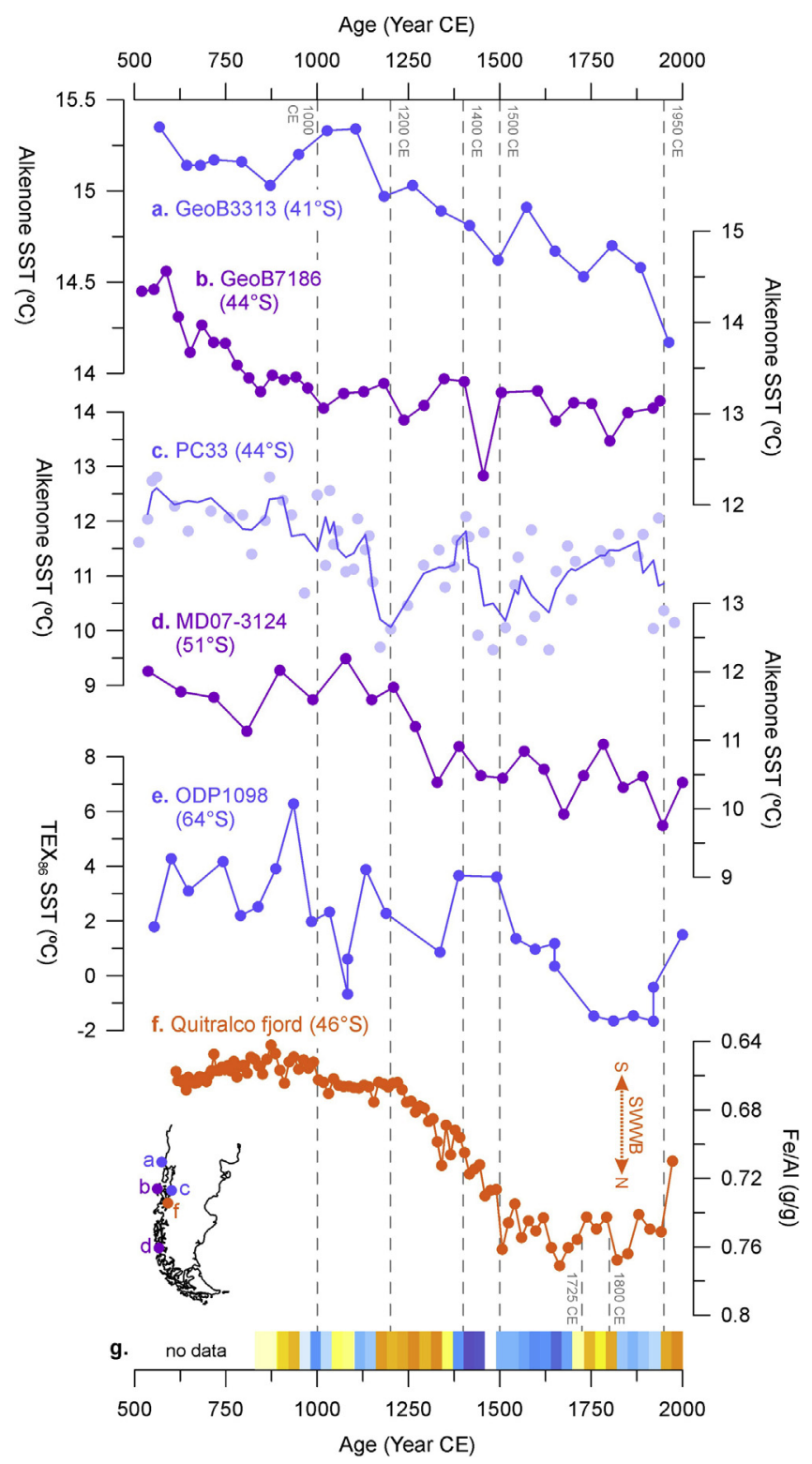

Fig. 8. Comparison between the PC29A precipitation seasonality reconstruction and temperature records from the southeastern Pacific, Patagonian fjords, and Antarctic Peninsula. The sea surface temperature (SST) records are organized from north to south: (a) GeoB3313 (Lamy et al., 2002), (b) GeoB7186 (Mohtadi et al., 2007), (c) PC33 (Jacaf fjord; Sepúveda et al., 2009), (d) MD07-3124 (Canal Concepción; Caniupán et al., 2014), (e) ODP 1098 (Shevenell et al., 2011). (f) PC29A precipitation seasonality reconstruction (this work). (g) Reconstruction of air temperature for South America (30-year standardized mean; PAGES 2k consortium, 2013). Warmer colors represent warmer air temperature and vice versa, as in the original article. (For interpretation of the references to color in this figure legend, the reader is referred to the web version of this article.) 
The four existing SST records from the Patagonian region $\left(41-51^{\circ} \mathrm{S}\right.$; Fig. $\left.8 \mathrm{a}-\mathrm{d}\right)$ display a consistent SST decrease of $1-1.5^{\circ} \mathrm{C}$ during the last millennium, although the timing of the onset of the cooling trend varies among sites. It starts as early as $600 \mathrm{CE}$ in core GeoB7186 (44 S; Mohtadi et al., 2007), around 1150 CE in GeoB3313

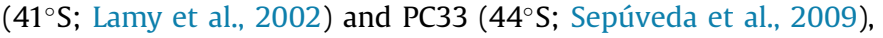
and around 1250 CE in MD07-3124 (51 S; Caniupán et al., 2014). These four records, which cover 10 degrees of latitude, all seem to point to a SST decrease of the southeastern Pacific that started between 600 and $1250 \mathrm{CE}$, and persisted until the last century. The relatively high variability of SSTs at site PC33 (Jacaf Fjord, $44^{\circ} \mathrm{S}$ ) during the last 800 years is likely due to the episodic influence of cold river water input since this site is located in a narrow fjord with several river inflows.

Comparison between these SST records and the PC29A paleohydrology record (Fig. 8f) indicates that low precipitation seasonality in the Quitralco fjord area, and therefore equatorward-shifted SWWB, is coeval with low SSTs in the southeastern Pacific and vice versa. The relation between the amplitude of SST and SWWB changes over the last 1400 years $\left(3-4^{\circ}\right.$ latitudinal shift of the SWWB and $1-1.5^{\circ} \mathrm{C} \mathrm{SST} \mathrm{decrease)} \mathrm{is} \mathrm{similar} \mathrm{to} \mathrm{the} \mathrm{relation} \mathrm{that} \mathrm{was}$ suggested for glacial-interglacial timescales, during which the SWWB migrated over 7-10 degrees of latitude and SSTs decreased by about $6^{\circ} \mathrm{C}$ (Lamy et al., 2004; Toggweiler et al., 2006). Our results therefore suggest that fluctuations in the latitudinal position of the SWWB during the late Holocene are tightly linked to sea surface temperature variability in the Southern Ocean and southeastern Pacific. The equatorward migration of the SWWB that started in $1200 \mathrm{CE}$ and peaked in 1500-1950 CE was clearly related to lower SSTs in the Southern Ocean and southeastern Pacific.

For glacial-interglacial timescales, the modeling results of Williams and Bryan (2006) suggest the following mechanism: largescale SST decrease reduces convection in the tropics causing a contraction of the Hadley cell, which in turn results in an equatorward shift of the SWWB. Although SSTs also seem to decrease in the equatorial Pacific during the late Holocene (Stott et al., 2004), the amplitude of the cooling $\left(<1{ }^{\circ} \mathrm{C}\right)$ seems too limited to cause a significant decrease in the strength of the Hadley cell. Instead, we suggest that the equatorward migration of the SWWB during the last millennium was caused by a strengthening of the polar cell, as reflected by the strong $\left(\sim 5^{\circ} \mathrm{C}\right)$ SST decrease around the Antarctic Peninsula (Fig. 8e; Shevenell et al., 2011). This hypothesis is supported by air temperature reconstructions from continental Antarctica (e.g., Masson et al., 2000), which show a $\sim 2{ }^{\circ} \mathrm{C}$ decrease between 1280 and $1900 \mathrm{CE}$ (Bertler et al., 2011). The influence of air temperature on the latitudinal position of the SWWB is further supported by the good agreement between variations in air temperature in South America (PAGES 2k consortium, 2013; Fig. 8g) and our Quitralco fjord record, which show concomitant changes at multi-centennial to multi-decadal timescales, with lower temperature being systematically associated with decreased precipitation seasonality over Quitralco fjord, and therefore northward migration of the SWWB. This relation is particularly striking for the 1725-1800 CE time-window (Fig. 8g), during which higher air temperature is coeval with a southward migration of the SWWB, in agreement with the decrease in precipitation recorded in nearby Lago Plomo (Elbert et al., 2011). The equatorward shift of the SWWB during the last millennium was very likely enhanced by increased sea-ice cover around Antarctica, as suggested by the sea-ice diatoms biomarker concentrations measured in ODP core 1098 (Etourneau et al., 2013), and by the sea-ice dependent $\delta^{18} \mathrm{O}$ record of WAIS divide (Steig et al., 2013). In addition, the gradual equatorward migration of the SWWB likely caused the northward migration of the northern branch of the ACC, which reinforced the decrease in SSTs off Patagonia during the second half of the last millennium.
The mechanism proposed above differs from the seesaw-type redistribution of heat between the hemispheres that was invoked to explain the migration of the SWWB during the last deglaciation (Anderson et al., 2009; Toggweiler, 2009). This suggests that the SWWB may respond to different forcing mechanisms at different timescales. For the late Holocene, solar forcing may play an important role, as suggested by Varma et al. (2011). In addition, the early onset of cooling and migration of the SWWB in the Southern Hemisphere during the last millennium (1200 CE, or as early as 1000 CE according to some records, see Figs. 7 and 8) compared to the onset of changes in climate associated to the Little Ice Age in the Northern Hemisphere (1400 CE; Haug et al., 2001; Mann et al., 2009) suggests a forcing mechanism predominantly influencing the Southern Hemisphere.

\section{Conclusions}

Geochemical and sedimentological data obtained on sediment core PC29A (Quitralco fjord, $46^{\circ} \mathrm{S}$ ) were successfully used to reconstruct late Holocene changes in precipitation seasonality in the Andes of northern Chilean Patagonia. Due to the distinct precipitation regimes that exist immediately to the north (strong precipitation seasonality) and to the south (year-round precipitation) of Quitralco fjord, relatively small latitudinal shifts of the SWWB in either direction result in large changes in precipitation seasonality. Our paleohydrological reconstruction can therefore be directly interpreted in terms of latitudinal shifts of the SWWB, reconciling most previously-published late Holocene records of SWWB variability in Patagonia. Our sediment record suggests a poleward-shifted SWWB between 600 and $1200 \mathrm{CE}$, followed by a gradual shift towards the equator between 1200 and $1500 \mathrm{CE}$, and stabilization in a sustained equatorward position between 1500 and $1950 \mathrm{CE}$. The most recent part of the record displays a return to a slightly poleward shifted SWWB, in agreement with recent trends observed in climatological data. Comparison with SST reconstructions off Chilean Patagonia shows a tight link between latitudinal variations of the SWWB and SSTs during the late Holocene, with the SWWB being systematically shifted poleward when SSTs are higher and vice versa. This pattern resembles the variability that occurs at glacial-interglacial timescales. We suggest that late Holocene variations in the SWWB are driven by changes in the strength of the polar cell, which responds to temperature variations at the high latitudes of the Southern Hemisphere. By comparison, tropical climate probably had little influence on the SWWB during the late Holocene. Finally, the early onset of SST decrease and SWWB equatorward migration compared to the Northern Hemisphere Little Ice Age suggests that the forcing mechanism predominantly influences the Southern Hemisphere. Extending our precipitation seasonality record to the entire Holocene would very likely solve the discrepancies that currently exist regarding the evolution of the SWWB during the Holocene.

\section{Acknowledgments}

We acknowledge the Chilean National Oceanographic Committee (CONA) for financial support to carry out the Cimar-7 Fiordo Program (Grant C7F 01-10 to Silvio Pantoja). The captain and crew of the AGOR Vidal Gormaz are thanked for their professional support during the expedition. Liviu Giosan and Jess Tierney (WHOI) are acknowledged for their help with the ITRAX XRF core scanner. We are grateful to Maureen Auro, Joanne Goudreau and Olivier Rouxel (WHOI) for making possible the geochemical measurements by FAAS, to Steve Manganini (WHOI) for providing access to the coulometer, to JanBerend Stuut and Inka Meyer (MARUM, Bremen, Germany) for sharing the Coulter grain size analyzer and running the end-member 
algorithm, to Nathalie Fagel (ULg, Belgium) for providing access to the x-ray diffractometer, and to Marco Coolen and Edward Sholkovitz (WHOI) for supplying some of the material used for sample preparation. The Chilean Dirección General de Aguas (DGA) and the Servicio Hidrográfico y Oceanográfico de la Armada (SHOA) provided the meteorological data presented in Fig. 1a and Appendix 3. We acknowledge the authors of data presented in Figs. 7 and 8 for making their results available. This research was supported by a BAEF fellowship (Belgian American Educational Foundation) and an EU FP6 Marie Curie Outgoing Fellowship to S. Bertrand. J. Sepúlveda was supported by Fundación Andes through the WHOI/University of Concepción agreement, and by a scholarship from the Graduate School of the University of Concepción. The Hanse-Wissenschaftskolleg (HWK) in Delmenhorst, Germany, provided support to S. Pantoja. S. Bertrand is currently a postdoctoral fellow of the Flemish Research Foundation (Belgium). This research contributes to the LOTRED-SA (PAGES 2k) initiative. Two anonymous reviewers provided detailed and constructive comments on an earlier version of this paper. The dataset presented in this article is available on PANGAEA: http://doi.pangaea.de/10.1594/PANGAEA.829370.

\section{Appendix A. Supplementary data}

Supplementary data related to this article can be found at http:// dx.doi.org/10.1016/j.quascirev.2014.09.021.

\section{References}

Anderson, R.F., Ali, S., Bradtmiller, L.I., Nielsen, S.H.H., Fleisher, M.Q., Anderson, B.E., Burckle, L.H., 2009. Wind-driven upwelling in the southern ocean and the deglacial rise in atmospheric $\mathrm{CO}_{2}$. Science 323, 1443-1448.

Aravena, J.C., Luckman, B.H., 2009. Spatio-temporal rainfall patterns in Southern South America. Int. J. Climatol. 29, 2106-2120.

Araya-Vergara, J.F., 1997. Geomorphological profiles of the fjords and longitudinal depression of North-Patagonia. Cienc. Tecnol. Mar 20, 3-22.

Bentley, M.J., Hodgson, D.A., Smith, J.A., Cofaigh, C.O., Domack, E.W., Larter, R.D., Roberts, S.J., Brachfeld, S., Leventer, A., Hjort, C., Hillenbrand, C.D., Evans, J., 2009. Mechanisms of Holocene palaeoenvironmental change in the Antarctic Peninsula region. Holocene 19, 51-69.

Bertler, N.A.N., Mayewski, P.A., Carter, L., 2011. Cold conditions in Antarctica during the Little Ice Age - implications for abrupt climate change mechanisms. Earth Planet. Sci. Lett. 308, 41-51.

Bertrand, S., Boës, X., Castiaux, J., Charlet, F., Urrutia, R., Espinoza, C., Lepoint, G., Charlier, B., Fagel, N., 2005. Temporal evolution of sediment supply in Lago Puyehue (Southern Chile) during the last $600 \mathrm{yr}$ and its climatic significance. Quat. Res. 64, 163-175.

Bertrand, S., Hughen, K.A., Lamy, F., Stuut, J.B.W., Torrejón, F., Lange, C.B., 2012a. Precipitation as the main driver of Neoglacial fluctuations of Gualas glacier, Northern Patagonian Icefield. Clim. Past 8, 519-534.

Bertrand, S., Hughen, K.A., Sepúlveda, J., Pantoja, S., 2012b. Geochemistry of surface sediments from the fjords of Northern Chilean Patagonia (44-47 ${ }^{\circ} \mathrm{S}$ ): spatial variability and implications for paleoclimate reconstructions. Geochim. Cosmochim. Acta 76, 125-146.

Blaauw, M., 2010. Methods and code for 'classical' age-modelling of radiocarbon sequences. Quat. Geochronol. 5, 512-518.

Boex, J., Fogwill, C., Harrison, S., Glasser, N.F., Hein, A., Schnabel, C., Xu, S., 2013. Rapid Thinning of the Late Pleistocene Patagonian Ice Sheet Followed Migration of the Southern Westerlies. Scientific Reports 3.

Brindley, G.W., Brown, G., 1980. Crystal structures of Clay Minerals and Their X-ray Identification. Mineralogical Society of London, UK.

Campbell, C., 1998. Late Holocene lake sedimentology and climate change in southern Alberta, Canada. Quat. Res. 49, 96-101.

Caniupán, M., Lamy, F., Lange, C.B., Kaiser, J., Kilian, R., Arz, H.W., León, T., Mollenhauer, G., Sandoval, S., De Pol-Holz, R., Pantoja, S., Wellner, J., Tiedemann, R., 2014. Holocene sea-surface temperature variability in the Chilean fjord region. Quat. Res. 82, 342-353.

Carter, S.J., Colman, S.M., 1994. Biogenic silica in Lake Baikal sediments - results from 1990-1992 American Cores. J. Gt. Lakes Res. 20, 751-760.

Cook, H.E., Johnson, P.D., Matti, J.C., Zemmels, I., 1975. Methods of sample preparation and X-ray diffraction data analysis, X-ray Mineralogy Laboratory, Deep Sea Drilling Project, University of California, Riverside. In: Hayes, D.E., Frakes, L.A., et al. (Eds.), Initial Reports of the Deep Sea Drilling Project. U.S. Govt. Printing Office, Washington, pp. 999-1007.

Elbert, J., Grosjean, M., von Gunten, L., Urrutia, R., Fischer, D., Wartenburger, R., Ariztegui, D., Fujak, M., Hamann, Y., 2011. Quantitative high-resolution winter
(JJA) precipitation reconstruction from varved sediments of Lago Plomo $47^{\circ} \mathrm{S}$ Patagonian Andes, AD 1530-2002. Holocene 22, 465-474.

Esper, J., Frank, D.C., Wilson, R.J.S., 2004. Climate reconstructions: low-frequency ambition and high-frequency ratification. EOS, Trans. Am. Geophys. Union 85 $113-120$.

Etourneau, J., Collins, L.G., Willmott, V., Kim, J.H., Barbara, L., Leventer, A. Schouten, S., Damste, J.S.S., Bianchini, A., Klein, V., Crosta, X., Masse, G., 2013 Holocene climate variations in the western Antarctic Peninsula: evidence for sea ice extent predominantly controlled by changes in insolation and ENSO variability. Clim. Past 9, 1431-1446.

Fletcher, M.S., Moreno, P.I., 2012. Vegetation, climate and fire regime changes in the Andean region of southern Chile $\left(38^{\circ} \mathrm{S}\right)$ covaried with centennial-scale climate anomalies in the tropical Pacific over the last 1500 years. Quat. Sci. Rev. 46, 46-56.

Garreaud, R., Vuille, M., Compagnucci, R., Marengo, J., 2009. Present-day South American climate. Palaeogeogr. Palaeoclimatol. Palaeoecol. 281, 180-195.

Garreaud, R., Lopez, P., Minvielle, M., Rojas, M., 2013. Large-scale control on the patagonian climate. J. Clim. 26, 215-230.

Giguet-Covex, C., Arnaud, F., Enters, D., Poulenard, J., Millet, L., Francus, P., David, F. Rey, P.J., Wilhelm, B., Delannoy, J.J., 2012. Frequency and intensity of highaltitude floods over the last $3.5 \mathrm{ka}$ in northwestern French Alps (Lake Anterne). Quat. Res. 77, 12-22.

Grangeon, T., Legout, C., Esteves, M., Gratiot, N., Navratil, O., 2012. Variability of the particle size of suspended sediment during highly concentrated flood events in a small mountainous catchment. J. Soil Sediment. 12, 1549-1558.

Guerra, A.J.T., Soares Da Silva, A., 2011. Predicting soil loss and runoff from forest roads and seasonal cropping systems in Brazil using WEPP. In: Morgan, R.P.C. Nearing, M.A. (Eds.), Handbook of Erosion Modelling. Wiley-Blackwell, Chichester, West Sussex, UK ; Hoboken, NJ, pp. 186-194.

Gut, B., 2008. Trees in Patagonia. Basel.

Haberzettl, T., Fey, M., Lucke, A., Maidana, N., Mayr, C., Ohlendorf, C., Schabitz, F., Schleser, G.H., Wille, M., Zolitschka, B., 2005. Climatically induced lake level changes during the last two millennia as reflected in sediments of Laguna Potrok Aike, southern Patagonia (Santa Cruz, Argentina). J. Paleolimnol. 33, 283-302.

Haug, G.H., Hughen, K.A., Sigman, D.M., Peterson, L.C., Rohl, U., 2001. Southward migration of the intertropical convergence zone through the Holocene. Science 293, 1304-1308.

Heusser, C.J., Streeter, S.S., 1980. A temperature and precipitation record of the past 16,000 years in southern Chile. Science 210, 1345-1347.

Hijmans, R.J., Cameron, S.E., Parra, J.L., Jones, P.G., Jarvis, A., 2005. Very high resolution interpolated climate surfaces for global land areas. Int. J. Climatol. 25, 1965-1978.

Hogg, A.G., Hua, Q., Blackwell, P.G., Niu, M., Buck, C.E., Guilderson, T.P., Heaton, T.J., Palmer, J.G., Reimer, P.J., Reimer, R.W., Turney, C.S.M., Zimmerman, S.R.H., 2013. SHCal13 southern hemisphere calibration, 0-50,000 years cal BP. Radiocarbon 55, 1889-1903.

Hooke, R.L., 2000. Toward a uniform theory of clastic sediment yield in fluvial systems. Geol. Soc. Am. Bull. 112, 1778-1786.

Huang, S.L., Sholkovitz, E.R., Conte, M.H., 2007. Application of high-temperature fusion for analysis of major and trace elements in marine sediment trap samples. Limnol. Oceanogr. Meth. 5, 13-22.

Jenny, B., Valero-Garcés, B.L., Urrutia, R., Kelts, K., Veit, H., Appleby, P.G., Geyh, M, 2002. Moisture changes and fluctuations of the Westerlies in Mediterranean Central Chile during the last 2000 years: the Laguna Aculeo record (3350'S). Quat. Int. 87, 3-18.

Kaufman, C.A., Lamoureux, S.F., Kaufman, D.S., 2011. Long-term river discharge and multidecadal climate variability inferred from varved sediments, southwest Alaska. Quat. Res. 76, 1-9.

Kilian, R., Lamy, F., 2012. A review of Glacial and Holocene paleoclimate records from southernmost Patagonia $\left(49-55^{\circ}\right.$ S). Quat. Sci. Rev. 53, 1-23.

Koffman, B.G., Kreutz, K.J., Breton, D.J., Kane, E.J., Winski, D.A., Birkel, S.D., Kurbatov, A.V., Handley, M.J., 2013. Centennial-scale shifts in the position of the Southern Hemisphere westerly wind belt over the past millennium. Clim. Past Discuss. 9, 3125-3174.

Kohfeld, K.E., Graham, R.M., de Boer, A.M., Sime, L.C., Wolff, E.W., Le Quéré, C., Bopp, L., 2013. Southern Hemisphere westerly wind changes during the Last Glacial Maximum: paleo-data synthesis. Quat. Sci. Rev. 68, 76-95.

Lamy, F., Gersonde, R., Winckler, G., Esper, O., Jaeschke, A., Kuhn, G. Ullermann, J., Martinez-Garcia, A., Lambert, F., Kilian, R., 2014. Increased dust deposition in the Pacific Southern Ocean during glacial periods. Science 343, 403-407.

Lamy, F., Hebbeln, D., Rohl, U., Wefer, G., 2001. Holocene rainfall variability in southern Chile: a marine record of latitudinal shifts of the Southern Westerlies. Earth Planet. Sci. Lett. 185, 369-382.

Lamy, F., Kaiser, J., Ninnemann, U., Hebbeln, D., Arz, H.W., Stoner, J., 2004. Antarctic timing of surface water changes off Chile and Patagonian ice sheet response. Science 304, 1959-1962.

Lamy, F., Kilian, R., Arz, H.W., Francois, J.P., Kaiser, J., Prange, M., Steinke, T., 2010. Holocene changes in the position and intensity of the southern westerly wind belt. Nat. Geosci. 3, 695-699.

Lamy, F., Ruhlemann, C., Hebbeln, D., Wefer, G., 2002. High- and low-latitude climate control on the position of the southern Peru-Chile current during the Holocene. Paleoceanography 17. 
Lenzi, M.A., Marchi, L., 2000. Suspended sediment load during floods in a small stream of the Dolomites (northeastern Italy). Catena 39, 267-282.

Luebert, F., Pliscoff, P., 2006. Sinopsis bioclimática y vegetacional de Chile, first ed. Editorial Universitaria, Santiago de Chile.

Mann, M.E., Zhang, Z.H., Rutherford, S., Bradley, R.S., Hughes, M.K., Shindell, D., Ammann, C., Faluvegi, G., Ni, F.B., 2009. Global signatures and dynamical origins of the Little Ice Age and Medieval climate anomaly. Science 326, 1256-1260.

Marcott, S.A., Shakun, J.D., Clark, P.U., Mix, A.C., 2013. A reconstruction of regional and global temperature for the past 11,300 years. Science 339, 1198-1201.

Masiokas, M.H., Villalba, R., Luckman, B.H., Lascano, M.E., Delgado, S., Stepanek, P., 2008. 20th-century glacier recession and regional hydroclimatic changes in northwestern Patagonia. Glob. Planet. Change 60, 85-100.

Masson, V., Vimeux, F., Jouzel, J., Morgan, V., Delmotte, M., Ciais, P., Hammer, C., Johnsen, S., Lipenkov, V.Y., Mosley-Thompson, E., Petit, J.R., Steig, E.J., Stievenard, M., Vaikmae, R., 2000. Holocene climate variability in Antarctica based on 11 ice-core isotopic records. Quat. Res. 54, 348-358.

Mayewski, P.A., Meredith, M.P., Summerhayes, C.P., Turner, J., Worby, A., Barrett, P.J., Casassa, G., Bertler, N.A.N., Bracegirdle, T., Garabato, A.C.N., Bromwich, D. Campbell, H., Hamilton, G.S., Lyons, W.B., Maasch, K.A., Aoki, S., Xiao, C., van Ommen, T., 2009. State of the Antarctic and Southern Ocean Climate System. Rev. Geophys. 47.

Meehl, G.A., Stocker, T.F., Collins, W.D., Friedlingstein, P., Gaye, A.T., Gregory, J.M., Kitoh, A., Knutti, R., Murphy, J.M., Noda, A., Raper, S.C.B., Watterson, I.G., Weaver, A.J., Zhao, Z.-C., 2007. Global climate projections. In: Solomon, S. Qin, D., Manning, M., Chen, Z., Marquis, M., Averyt, K.B., Tignor, M., M, H.L. (Eds.), Climate Change 2007: the Physical Science Basis. Contribution of Working Group I to the Fourth Assessment Report of the Intergovernmental Panel on Climate Change Cambridge University Press, Cambridge, United Kingdom and New York, NY, USA.

Meza, F.J., 2013. Recent trends and ENSO influence on droughts in Northern Chile: an application of the Standardized Precipitation Evapotranspiration Index. Weather Clim. Extrem. 1, 51-58.

Miller, A., 1976. The climate of Chile. In: Schwerdtfeger, W. (Ed.), Climates of Centra and South America. Elsevier Scientific Pub. Co, Amsterdam ; New York, pp. 107-134.

Milliman, J.D., 1997. Fluvial sediment discharge to the sea and the importance of regional tectonics. In: Ruddiman, W.F. (Ed.), Tectonic Uplift and Climate Change. Plenum Press, New York, pp. 239-257.

Minetti, J.L., Vargas, W.M., Poblete, A.G., Acuna, L.R., Casagrande, G., 2003. Nonlinear trends and low frequency oscillations in annual precipitation over Argentina and Chile, 1931-1999. Atmosfera 16, 119-135.

Mohtadi, M., Romero, O.E., Kaiser, J., Hebbeln, D., 2007. Cooling of the southern high latitudes during the Medieval Period and its effect on ENSO. Quat. Sci. Rev. 26, 1055-1066.

Moreno, P.I., Francois, J.P., Moy, C.M., Villa-Martinez, R., 2010. Covariability of the Southern Westerlies and atmospheric $\mathrm{CO}_{2}$ during the Holocene. Geology 38, $727-730$.

Moreno, P.I., Francois, J.P., Villa-Martinez, R.P., Moy, C.M., 2009. Millennial-scale variability in Southern Hemisphere westerly wind activity over the last 5000 years in SW Patagonia. Quat. Sci. Rev. 28, 25-38.

Moreno, P.I., Vilanova, I., Villa-Martinez, R., Garreaud, R.D., Rojas, M., De PolHolz, R., 2014. Southern Annular Mode-like changes in southwestern Patagonia at centennial timescales over the last three millennia. Nat. Commun. 5 , 4375.

Mortlock, R.A., Froelich, P.N., 1989. A simple method for the rapiddetermination of biogenic opal in Pelagic Marine-Sediments. Deep-Sea Res. 36, 1415-1426.

Murray, R., Miller, D., Kryc, K., 2000. Analysis of Major and Trace Elements in Rocks, Sediments, and Interstitial Waters by Inductively Coupled Plasma-atomic Emission Spectrometry (ICP-AES). ODP Technical Note, pp. 1-27.

Naranjo, J.A., Stern, C.R., 1998. Holocene explosive activity of Hudson Volcano, southern Andes. Bull. Volcanol. 59, 291-306.

Neukom, R., Luterbacher, J., Villalba, R., Kuttel, M., Frank, D., Jones, P.D., Grosjean, M., Esper, J., Lopez, L., Wanner, H., 2010. Multi-centennial summer and winter precipitation variability in southern South America. Geophys. Res. Lett. 37.

Noren, A.J., Bierman, P.R., Steig, E.J., Lini, A., Southon, J., 2002. Millennial-scale storminess variability in the northeastern United States during the Holocene epoch. Nature 419, 821-824.

PAGES $2 \mathrm{k}$ consortium, 2013. Continental-scale temperature variability during the past two millennia. Nat. Geosci. 6, 339-346.

Pankhurst, R.J., Weaver, S.D., Herve, F., Larrondo, P., 1999. Mesozoic-cenozoic evolution of the North Patagonian Batholith in Aysen, southern Chile. J. Geol. Soc. Lond. 156, 673-694.

Parris, A.S., Bierman, P.R., Noren, A.J., Prins, M.A., Lini, A., 2010. Holocene paleostorms identified by particle size signatures in lake sediments from the northeastern United States. J. Paleolimnol. 43, 29-49.

Quintana, J., Aceituno, P., 2006. Trends and interdecadal variability of rainfall in Chile. In: 8th ICSHMO, Foz do Iguaçu, Brazil, pp. 371-372.

Quintana, J.M., Aceituno, P., 2012. Changes in the rainfall regime along the extratropical west coast of South America (Chile): 30-43요 Atmosfera 25 $1-22$.

Reid, I., Frostick, L.E., 1994. Fluvial sediment transport and deposition. In: Pye, K. (Ed.), Sediment Transport and Depositional Processes. Blackwell Scientific Publications, Oxford, pp. 89-155.
Salinas, C.X., Mendieta, J., 2013. Mitigation and adaptation investments for desertification and climate change: an assessment of the socioeconomic return. Mitig. Adapt Strateg. Glob. Change 18, 659-672.

Sen Gupta, A., Santoso, A., Taschetto, A.S., Ummenhofer, C.C., Trevena, J., England, M.H., 2009. Projected changes to the southern hemisphere ocean and sea ice in the IPCC AR4 climate models. J. Clim. 22, 3047-3078.

Schimpf, D., Kilian, R., Kronz, A., Simon, K., Spotl, C., Worner, G., Deininger, M., Mangini, A., 2011. The significance of chemical, isotopic, and detrital components in three coeval stalagmites from the superhumid southernmost Andes $\left(53^{\circ} \mathrm{S}\right)$ as high-resolution palaeo-climate proxies. Quat. Sci. Rev. 30, $443-459$.

Sepúlveda, J., Pantoja, S., Hughen, K.A., Bertrand, S., Figueroa, D., León, T., Drenzek, N.J., Lange, C., 2009. Late Holocene sea-surface temperature and precipitation variability in northern Patagonia, Chile (Jacaf Fjord, 44 $\mathrm{S}$ ). Quat. Res. 72, 400-409.

Sernageomin, 2003. Mapa geologico de Chile version digital, escala 1/1.000.000.

Shevenell, A.E., Ingalls, A.E., Domack, E.W., Kelly, C., 2011. Holocene Southern Ocean surface temperature variability west of the Antarctic Peninsula. Nature 470, $250-254$.

Shindell, D.T., Schmidt, G.A., 2004. Southern Hemisphere climate response to ozone changes and greenhouse gas increases. Geophys. Res. Lett. 31.

SHOA, 2004. Canales Erraruiz, Costa y Estero Elefantes, Bathymetric Map 1/70.000.

Sievers, H.A., Silva, N., 2008. Water masses and circulation in austral Chilean channels and fjords. In: Silva, N., Palma, S. (Eds.), Progress in the Oceanographic Knowledge of Chilean Interior Waters, from Puerto Montt to Cape Horn. Comité Oceanográfico Nacional-Pontificia Universidad Católica de Valparaíso, Valparaiso, Chile, pp. 53-58.

Silva, N., Guzmán, D., 2006. Condiciones oceanográficas físicas y químicas, entre boca del guafo y fiordo aysén (crucero cimar 7 fiordos). Cienc. Tecnol. Mar 29, 25-44.

Sime, L.C., Kohfeld, K.E., Le Quéré, C., Wolff, E.W., de Boer, A.M., Graham, R.M., Bopp, L., 2013. Southern Hemisphere westerly wind changes during the Last Glacial Maximum: model-data comparison. Quat. Sci. Rev. 64, 104-120.

Steig, E.J., Ding, Q.H., White, J.W.C., Kuttel, M., Rupper, S.B., Neumann, T.A., Neff, P.D., Gallant, A.J.E., Mayewski, P.A., Taylor, K.C., Hoffmann, G., Dixon, D.A., Schoenemann, S.W., Markle, B.R., Fudge, T.J., Schneider, D.P., Schauer, A.J., Teel, R.P., Vaughn, B.H., Burgener, L., Williams, J., Korotkikh, E., 2013. Recent climate and ice-sheet changes in West Antarctica compared with the past 2,000 years. Nat. Geosci. 6, 372-375.

Stern, C.R., Moreno, H., Lopez-Escobar, L., Clavero, J.E., Lara, L.E., Naranjo, J.A., Parada, M.A., Skewes, M.A., 2007. Chilean volcanoes. In: Moreno, T., Gibbons, W. (Eds.), The Geology of Chile. Geological Society of London, London, pp. 147-178.

Stott, L., Cannariato, K., Thunell, R., Haug, G.H., Koutavas, A., Lund, S., 2004. Decline of surface temperature and salinity in the western tropical Pacific Ocean in the Holocene epoch. Nature 431, 56-59.

Strub, P.T., Mesias, J.M., Montecino, V., Ruttlant, J., Salinas, S., 1998. Coastal ocean circulation off western South America. In: Robinson, A.R., Brink, K.H. (Eds.), The Sea. Wiley, New York, pp. 273-315.

Thompson, D.W.J., Solomon, S., Kushner, P.J., England, M.H., Grise, K.M., Karoly, D.J., 2011. Signatures of the Antarctic ozone hole in Southern Hemisphere surface climate change. Nat. Geosci. 4, 741-749.

Toggweiler, J.R., 2009. Shifting westerlies. Science 323, 1434-1435.

Toggweiler, J.R., Russell, J.L., Carson, S.R., 2006. Midlatitude westerlies, atmospheric $\mathrm{CO}_{2}$, and climate change during the ice ages. Paleoceanography 21.

Vandekerkhove, E., 2014. The volcanic ash soils of northern Chilean Patagonia $\left(44^{\circ}-48^{\circ} \mathrm{S}\right)$ : Distribution, weathering and influence on river chemistry. MSc thesis. Ghent University, Belgium, p. 72.

Varma, V., Prange, M., Lamy, F., Merkel, U., Schulz, M., 2011. Solar-forced shifts of the Southern Hemisphere Westerlies during the Holocene. Clim. Past 7, 339-347.

Vera, C., Silvestri, G., Liebmann, B., Gonzalez, P., 2006. Climate change scenarios for seasonal precipitation in South America from IPCC-AR4 models. Geophys. Res. Lett. 33.

Verardo, D.J., Froelich, P.N., Mcintyre, A., 1990. Determination of organic-carbon and nitrogen in Marine-Sediments using the Carlo-Erba-Na-1500 analyzer. DeepSea Res. 37, 157-165.

Vieira, R., 2002. Morfogénesis y dinámica de las vertientes submarinas en la costa de fiordos de Norpatagonia, Chile. MSc thesis. Universidad de Chile, Santiago, p. 101.

Villalba, R., Lara, A., Masiokas, M.H., Urrutia, R., Luckman, B.H., Marshall, G.J., Mundo, I.A., Christie, D.A., Cook, E.R., Neukom, R., Allen, K., Fenwick, P., Boninsegna, J.A., Srur, A.M., Morales, M.S., Araneo, D., Palmer, J.G., Cuq, E., Aravena, J.C., Holz, A., LeQuesne, C., 2012. Unusual southern hemisphere tree growth patterns induced by changes in the southern annular mode. Nat. Geosci 5, 793-798.

Villa-Martínez, R., Moreno, P.I., 2007. Pollen evidence for variations in the southern margin of the westerly winds in SW Patagonia over the last 12,600 years. Quat. Res. 68, 400-409.

Waldmann, N., Ariztegui, D., Anselmetti, F.S., Austin, J.A., Moy, C.M., Stern, C. Recasens, C., Dunbar, R.B., 2010. Holocene climatic fluctuations and positioning of the Southern Hemisphere westerlies in Tierra del Fuego ( $\left.54^{\circ} \mathrm{S}\right)$, Patagonia. J. Quat. Sci. 25, 1063-1075.

Waldmann, N., Borromei, A.M., Recasens, C., Olivera, D. Martínez, M.A. Maidana, N.I., Ariztegui, D., Austin Jr., J.A., Anselmetti, F.S., 2014. Integrated reconstruction of Holocene millennial-scale environmental changes in Tierra 
del Fuego, southernmost South America. Palaeogeogr. Palaeoclimatol. Palaeoecol. 399, 294-309.

Walling, D.E., Moorehead, P.W., 1989. The particle-size characteristics of fluvial suspended sediment - an overview. Hydrobiologia 176, 125-149.

Walling, D.E., Owens, P.N., Waterfall, B.D., Leeks, G.J.L., Wass, P.D., 2000. The particle size characteristics of fluvial suspended sediment in the Humber and Tweed catchments, UK. Sci. Total Environ. 251, 205-222.
Warren, C.R., 1993. Rapid recent fluctuations of the Calving San-Rafael glacier, Chilean Patagonia - climatic or non-climatic. Geogr. Ann. A 75, 111-125.

Weltje, G.J., Prins, M.A., 2007. Genetically meaningful decomposition of grain-size distributions. Sediment. Geol. 202, 409-424.

Williams, G.P., Bryan, K., 2006. Ice age winds: an aquaplanet model. J. Clim. 192, 1706-1715. 